\title{
1311 M. VOPLAUKIO MŪŠIS: PRIEŽASTYS, EIGA, KARYBOS ASPEKTAI, ISTORINĖ ATMINTIS
}

\author{
Ričardas Dediala \\ Vilniaus universitetas
}

\section{IVADAS}

Viduramžių lietuvių karyba sulaukia nemažai istorikų dėmesio, tačiau dažniausiai nuodugniai analizuojami pergalingi mūšiai, kaip antai: Saulès (1236 m.), Durbès (1260 m.), Karusès (1270 m.), Aizkrauklès (1279 m.), Žalgirio kautynès (1410 m.). Karybos formų pažinimo prasme neturi reikšmès, tai buvo pergalė ar pralaimèjimas, svarbu - ką užfiksavo šaltiniai, todèl ir pralaimètų mūšių (ar smulkių susidūrimų) analizè leidžia geriau suprasti karo meną. Kaip ir $1311 \mathrm{~m}$. balandžio 7 d. įvykusị Voplaukio mūši, kuris didžiajam kunigaikščiui Vyteniui buvo nesèkmingas, tačiau karybos žinių požiūriu suteikia daug ịdomios informacijos apie tam tikrus karybos aspektus. Be to, šaltiniuose, aprašančiuose šị susidūrimą, gausu savigyros, Vokiečių ordino (toliau - Ordino) propagandinių išpuolių prieš Lietuvos Didžiąą Kunigaikštystę XIV a. pradžios ịvykių fone, kai siekiant sureguliuoti lietuvių santykius su Ryga buvo kalbama apie Vytenio krikštą ir apskritai kuriami glaudesni santykiai su krikščioniškuoju pasauliu.

Šio straipsnio tikslas - remiantis istorijos šaltiniais išanalizuoti $1311 \mathrm{~m}$. ivvykusị Voplaukio mūšĭ, atskleisti jo priežastis, aprašyti eigą ir padarinius, nuodugniau aptarti karybos formas. 


\section{ŠALTINIAI IR LITERATŪRA}

Šaltiniai. Voplaukio kautynių atgarsių esama daugiau nei dešimtyje šaltinių. Chronologiškai artimiausias tekstas pateiktas XIV a. pirmoje pusèje Vokiečiu ordino brolio ir kunigo Petro Dusburgiečio parašytoje Prūsijos žemés kronikoje. ${ }^{1}$ Ši kronika $1340 \mathrm{~m}$. buvo išversta ị vokiečių kalbą ir sueiliuota Ordino didžiụjų magistrų kapeliono Mikalojaus Jerošiniečio ${ }^{2}$. Tekste daug pakeitimų, praleidimų, papildymų, galejusių atsirasti įtraukus nežinomų Petro Dusburgiečio epizodų ${ }^{3}$. Mikalojaus Jerošiniečio Voplaukio mūšio aprašymas kelia daug klausimų, nes apskritai yra vienintelis šaltinis, kuriame taip smulkiai aprašyta šio mūšio eiga. Reikètų turèti omenyje, kad kronikos vertejas pats, kaip amžininkas, galëjo žinoti apie daugeli $1311 \mathrm{~m}$. îvykių ir ịtraukti papildomų ir ypatingo demesio vertų žinių apie šị susidūrimą ${ }^{4}$. Istoriografijoje pažymèta, jog abejoti Jerošiniečiu nèra pagrindo, nes Dusburgiečio tekstą jis praplèsdavo dažniausiai tuomet, kai buvo aprašomi kokie nors itin svarbūs ịvykiai, kurie lèmé Ordino likimą̧.

Apie mūšs trumpai pasakoja Ordino heroldo Vygando Marburgiečio Naujoji Prūsijos kronika ${ }^{6}$, rašyta 1394 m., taip pat (tačiau neišsamiai) XIV a. pr. datuojamas Sembos kanauninkas ${ }^{7}, \mathrm{XV}$ a. Torunes analistas ${ }^{8}$, XIV a. Trumpieji Prūsijos analai ${ }^{9}, \mathrm{XV}$ a. Prūsu ekspediciju analai ${ }^{10}$, Lietuvos Didžiosios Kunigaikštystès istoriko Motiejaus Strijkovskio gauti ir

1 Petri de Dusburg Chronicon terrae Prussiae // Scriptores rerum Prussicarum (toliau SRP), 1861, Bd. 1, s. 176-177; Petras Dusburgietis. Prūsijos žemès kronika. Vilnius, 1985, p. 256-259.

2 Di Kronike von Pruzinlant des Nicolaus von Jeroschin // SRP, 1861, Bd. 1, s. 575-579.

3 Baronas D., Mačiulis D. Pilènai ir Margiris: istorija ir legenda. Vilnius, 2010, p. 29.

4 Baltų religijos ir mitologijos šaltiniai (sudarė N. Vèlius). Vilnius, 1996, t. 1, p. 356; Ivinskis Z. Rinktiniai raštai. Roma, 1986, t. 2, p. 77.

5 Kregždys R. Pr. Romow: tekstologinè, etimologinè, mitologinè analizė // Baltų onomastikos tyrimai. Vilnius, 2011, t. 2, p. 159.

6 Die Chronik Wingands von Marbug // SRP, 1863, Bd. 2, s. 454-455; Vygandas Marburgietis. Naujoji Prūsijos kronika. Vilnius, 1999, p. 64-66.

7 Canonici Sambiensis // SRP, 1861, Bd. 1, s. 282, 285.

8 Annalista Thorunensis // SRP, 1866, Bd. 3, s. 64.

9 Kurze Preussische annalen // SRP, 1866, Bd. 3, s. 3

10 Annales Expeditialis Prussici 1238-1414// SRP, 1866, Bd. 3, s. 9. 
išversti ị lenkų kalbą XIV a. vid. Roneburgo analai (dar vadinami Raunos metraščiu $)^{11}$, XIV a. vid. Olyvos kronika ${ }^{12}$. Platesnį aprašymą randame XV a. pirmojoje pusejje rašytoje Vyresniojoje didžiuju magistru kronikoje $e^{13}$. Šios kronikos pagrindinis žinių šaltinis buvo Mikalojaus Jerošiniečio versta Petro Dusburgiečio kronika. Fragmentiškas mūšio aprašymas pateko į XV a. pab. parašytą Jaunesniaja didžiuju magistrų kroniką ${ }^{14}$. Voplaukio ịvykius aprašo ir lenku istorikas kronikininkas Janas Długoszas (1415-1480), jo kronikoje Garbingosios Lenkijos karalystès metraščiai arba kronikos (XV a. pab.) pakartoti Petro Dusburgiečio Prūsijos žemès kronikos žodžiai ${ }^{15}$. J. Długoszo tradicija seke ir Motiejus Miechovietis (1457-1523) ${ }^{16}$.

Literatūra. Pradedant XVI a., žymesni autoriai pateikdavo nemažai Voplaukio mūšio interpretacijų, žinių jie sẻmėsi iš Petro Dusburgiečio ir Mikalojaus Jerošiniečio. Iš tokių galima paminèti Luką Davidą (apie 1503-1583) ${ }^{17}$, Motiejų Strijkovski (apie 1547-1593) ${ }^{18}$, Aleksandrą Guagninị $(1538-1614)^{19}, 1582 \mathrm{~m}$. lenkų kalba pirmą kartą Prūsijos istoriją parašiusị Martyną Murinijų (gyvenimo metai nežinomi) ${ }^{20}$, Lietuvos istorijos

11 Die Annalen und das Necrologium von Ronneburg // SRP, 1863, Bd. 2, s. 145.

12 Die altere chronik von Oliva // SRP, 1861, Bd. 1, s. 710.

13 Die Äeltere Hochmeisterchronik // SRP, 1866, Bd. 3, s. 586.

14 Der Jüngere Hochmeisterchronik // SRP, 1874, Bd. 5, s. 111 (šioje kronikoje Vytenis klaidingai vadinamas didžiuoju kunigaikščiu Vytautu - „coninck Wittolt“).

15 Jana Długosza kanonika krakowskiego Dziejów polskich ksiąg dwanaście. Kraków, 1868 , t. 3, ks. 9, 10, s. 59-60.

16 Mathias de Miechow. Chronica Polonorum. Cracoviae, 1521, lib. 4, cap. 13, fol. 215-216.

17 Lucas David. Preussische Chronik, hrsg. von E. Hennig. Königsberg. 1813, Bd. 5, s. $169-174$

18 Stryjkovski M. Kronika polska, litewska, żmódzka i wszystkiéj Rusi. Warszawa, 1846, t. 1, s. 350-351.

19 Z kroniki Sarmacyi europskiekiej Alexandra Gwagnina z Werony: opisane Polski, W. Ks. litewskiego, ziemie ruskiej, ziemie pruskiej, ziemie inflantskiej, ziemie żmudzkiej. Kraków, 1860, s. 68-69.

20 Murzyński M. Kronika, abo Opisanie ziemie y Mistrzów Pruskich, ná Polskie z Niemieckiego przełożona, z przydániem rzeczy pámięći godnych z rozmáitych Kronik zebránych. Przez Marcina Muryniusa niekiedy wydána: A teraz po wtoré ná wielu mieyscách popráwiona y do Druku podána. W Krakowie, 1606, s. 66; Marcin Murinius. Kronika Mistrzów Pruskich. Olsztyn, 1989, s. 16, 113. 
autorių Albertą Vijūką-Kojelavičių (1609-1677)21. XIX a. atsirado profesionalesnių darbų, kuriuose galima rasti nemažai vertingos informacijos. Pažymètinas Simono Daukanto darbas „Istorija žemaitiška ${ }^{22}$ “, kuriame, nors ir fragmentiškai, gana tiksliai, remiantis šaltiniais, aprašytas mūšis. Detalią Voplaukio mūšio analizę atliko vokiečių istorikas Johanas Voigtas, jis mūšiui skyrè tris puslapius ${ }^{23}$. Juo sekè žymusis Lietuvos istorikas Teodoras Narbutas savo Lietuviu tautos istorijoje ${ }^{24}$ XX a. istoriografijoje ypatingo dèmesio šiam mūšiui neskirta. Platesnị mūšio aprašymą pateikè tik K. Sideravičius kolektyvineje monografijoje apie lietuvių karą su kryžiuočiais. Jo darbe ịdemiau pažvelgta ị Vytenio ịrengtą ịtvirtintą stovyklą ir vèliau Ordino skleistą propagandą apie lietuvius ${ }^{25}$.

Apie Voplaukị yra užsiminęs Edvardas Gudavičius. Jis apibūdino mūši trumpai: „1311 m. balandžio mènesị jis nusiaubė Varmiją ir Bartą. Tačiau grižtančią lietuvių kariuomenę ties Vaplaukiu pavijo didysis komtūras Henrikas Plockè su didelemis pajėgomis (150 ordino riterių) ir skaudžiai sumušè. Vaplaukio pralaimejjimas kurị laiką sutrikdè lietuvių puolimus ị Prūsiją ir leido ordinui dar labiau sustiprinti savo ofenzyvą. $1311 \mathrm{~m}$. vasarą beveik vienu metu 1,5 tūkstančio kryžiuočių kariuomenė nuniokojo Pagraudę, o 2 tūkstančių - Šalčininkus. Šalčininkų užpuolimas buvo ypač skaudus: netikètai ịsiveržta ị didžiojo kunigaikščio domeno gilumą, sugriautos 3 pilys, vien ị nelaisvę išvaryta 700 žmonių. Šiam žygiui vadovavo Vaplaukio nugalètojas Henrikas Plockè, pasirodęs kaip gabus ir veiklus taktikas. ${ }^{26 "}$

Romo Batūros ir Deimanto Karvelio parašytoje knygoje apie karinius susidūrimus randame gana trumpą Voplaukio mūšio aprašymą: „Balandị nusiaubę Varmę, kovèsi ties Vaplaukiu, Bartos žemèje. Persvara buvo

21 Vijūkas-Kojelavičius A. Lietuvos istorija: pirma ir antra dalis. Kaunas, 1989, p. 188-190.

22 Daukantas S. Istorija žemaitiška. Vilnius, 1995, t. 1, p. 508-510.

23 Voigt J. Geschichte Preussens. Königsberg, 1830, Bd. 4, s. 279-282.

24 Narbutas T. Lietuvių tautos istorija. Vilnius, 1997, t. 4, p. 354-355.

25 Sideravičius K. Lietuvos gynimasis nuo sustiprejjusios kryžiuočių agresijos 1295-1324 m. // Lietuvių karas su kryžiuočiais. Vilnius, 1964, p. 200.

26 Gudavičius E. Lietuvos istorija. Vilnius, 1999, t. 1, p. 81-82. 
kryžiuočių pusėje, todèl lietuviai skubiai pasitraukè “27. Tik keliais sakiniais apie ši susidūrimą informuoja Zenonas Ivinskis ${ }^{28}$, Darius Baronas ${ }^{29}$, S. C. Rowellas ${ }^{30}$, Jonas Vaičenonis ${ }^{31}$ ir Werneris Paravicinis ${ }^{32} .2013$ m. pasirodžiusiame kolektyviame apibendrinamajame darbe apie žymiausius Lietuvos mūšius ir karines operacijas apie Voplaukio mūšị neužsimenama, tačiau be jokios priežasties pateikiamas Vytenio žygio ị Sembą ir Notangą per 1311 metų Užgavėnes epizodas ${ }^{33}$, nors praejjus vos mėnesiui po šio puolimo ịvyks šiame straipsnyje analizuojamos kautynès. Gana plačiai ši susidūrimą aprašè amerikietis istorikas Williamas Urbanas, gana nuosekliai naudojęs pagrindinius šaltinius ir istoriografiją ${ }^{34}$. Disertacijos pagrindu 2004 m. išleistoje lenko istoriko Dariuszo Prekopo monografijoje ${ }^{35}$ apie 1283-1325 m. Ordino karą su Lietuva Voplaukio mūšiui skirta nemažai dèmesio aptariant ne tik jo eigą, bet ir Vytenio $1311 \mathrm{~m}$. žygių ì Prūsiją priežastis.

27 Batūra R., Karvelis D. Kovų istorijos. I knyga. Nuo seniausių laikų iki XX amžiaus. Vilnius, 2009, p. 48.

28 Ivinskis Z. Lietuvos istorija. Iki Vytauto Didžiojo mirties. Roma, 1978, p. 220.

${ }^{29}$ Baronas D. Kariuomenè // Lietuvos istorija. XIII a.-1385 m., t. 3, p. 384; Baronas D. Lietuvių karyba XIII a. // Karo archyvas, 2000, t. 16, p. 33, 42; Baronas D. Trys Vilniaus kankiniai: gyvenimas ir istorija. Vilnius, 2000, p. 103-106.

30 Rowell S. C. Iš viduramžių ūkų kylanti Lietuva: pagonių imperija Rytų ir Vakarų Europoje, 1295-1345. Vilnius, 2001, p. 259.

31 Vaičenonis J. Lietuvos karyba: nuo baltų iki XXI amžiaus: kariuomené, fortifikacija, mūšiai ir karvedžiai. Kaunas, 2011, p. 37.

32 Paravicini W. Die Preussenreisen des europäischen Adels. Sigmaringen, 1995, teil 2, s. 65 .

33 Batūra R. Irpenès mūšis apie 1325 m. // Žymiausi Lietuvos mūšiai ir karinès operacijos (atsakingasis redaktorius ir sudarytojas Karolis Zikaras). Vilnius, 2013, p. 33.

34 Urban W. Kryžiaus karas Žemaitijoje. Vilnius, 2005, p. 78-81.

35 Prekop D. Wojna zakonu krzyżackiego z Litwą w latach 1283-1325. Toruń, 2004, s. $117-120$. 


\section{DIDŽIOJO KUNIGAIKŠČIO VYTENIO POLITIKA}

Prasidejus nuolatiniam karui su Ordinu (nuo 1283 m.) ${ }^{36}$, padaugejo karinių susidūrimų, abi kariaujančios pusès rezgè vis drastiškesnius antpuolius. 1295 m. Lietuvos didžiuoju kunigaikščiu tapęs Vytenis neketino nusileisti Ordino karinei agresijai, todèl veike taliono principu. Tačiau Vytenio veiksmų negalime vadinti bekompromise kova su krikščioniškuoju pasauliu. Tai puikiai iliustruoja 1298 m. jo su Rygos miestu sudarytos paliaubos. Apskritai apie šias paliaubas sužinome iš $1298 \mathrm{~m}$. kovo $30 \mathrm{~d} .{ }^{37}$ Rygos miesto ir Daugavgryvos abato pranešimo, kuriame kalbama apie paliaubų sutartị ir planuojamą krikštą. Tačiau tai tik informacinis laiškas, ir tikslios datos nežinome, bet paliaubos turèjo būti sudarytos prieš kovo 30 d. Jos truko iki 1313 m. ${ }^{38}$ Tokiu būdu iš dalies buvo sukaustyta Vokiečių ordino livoniškoji šaka, kuri turejjo tvarkytis su rygiečiais, dabar jau glaudžiai bendradarbiaujančiais su lietuviais.

1298 m. birželio $1 \mathrm{~d}$. prie Turaidos pilies buvo sumušti Livonijos kryžiuočiai. Šioje kovoje žuvo Livonijos žemès magistras Brunonas, Felino

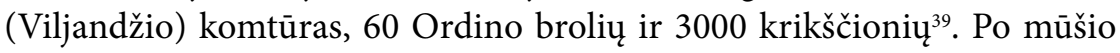
sunaikinta Bertoldsmiulès pilis ${ }^{40}$. Iki pat $1313 \mathrm{~m}$. vyko intensyvi ir permaininga kova. İsitraukęs ị Rygos ir Ordino konfliktą ir kryžiuočių kovas Livonijos teritorijoje, Vytenis beveik visą savo valdymo laikotarpi Lietuvai garantavo ganètinai ramią padetti šiauriniame fronte. Žinoma, būta ir pralaimejjimų, tačiau galingų smūgių šiuo taikos laikotarpiu pavyko išvengti. Situacija Prūsijoje buvo kiek kitokia. Intensyvaus karo metu ilgesnių

\footnotetext{
36 Nuolatinio karo apibrèžimas taikomas antrajai karo su kryžiuočiais fazei (12831411 m.). Iš viso skiriamos trys fazès: Baranauskas T. Lietuvos politiniai santykiai su Vakarų Europa XIII-XV a. // Kultūros barai, 2006, nr. 10, p. 69.

37 Chartularium Lithuaniae res gestas magni ducis Gedeminne illustrans. Gedimino laiškai. Tekstus, vertimus bei komentarus parengè S. C. Rowell. Vilnius, 2003, p. 14-15.

38 Ten pat, p. 23

39 Hermanni de Wartberge Chronicon Livoniae // SRP, 1863, Bd. 2, s. 56. Kronikininkas Petras Dusburgietis nurodo, kad žuvo Brunonas, 22 Ordino broliai ir 1500 krikščionių karių. Lietuviai prarado 800 vyrų: Petri de Dusburg Chronicon terrae Prussiae // SRP, 1861, Bd. 1, s. 163.

40 Hermanni de Wartberge Chronicon Livoniae // SRP, 1863, Bd. 2, s. 54.
} 
paliaubų tikètis buvo naivu. Vokiečių ordinas Vytenio valdymo laikais (1295-1315 m.) i Lietuvą surengè 35 žygius. Inirtingai buvo puolamos Panemunès pilys. Didysis kunigaikštis ị abi Ordino atšakas - Livonijos ir Prūsijos - surengè tik apie 14 žygių. Dauguma smūgių Lietuvai buvo suduoti iš Prūsijos, tad galime numanyti, kad Vytenis puikiai suvokè Prūsijos kryžiuočių pajėgumą, todèl intensyviau kariavo su Prūsijos kryžiuočiais. Vis dèlto, jeigu panagrinèsime organizuotų žygių maršrutus, pamatysime, kad abiem kryptimis buvo žygiuota po 7 kartus $^{41}$. Tokia situacija rodo tikruosius Livonijos kryžiuočių pajėgumus XIII a. pab. - XIV a. pr., t. y. iš karto po Žiemgalos nukariavimo ir konflikto su Ryga pradžioje. Kyla klausimas: kodèl taip intensyviai stengtasi kariauti dviem frontais, jei šiaurinèje pusejje prieš Ordiną buvo sudaryta itin palanki sąjunga? Atsakymo, mūsų manymu, reikètų ieškoti Vokiečių ordino karinèje strategijoje.

Vytenio pirmtakų ir jo paties valdymo laikais buvo susidurta su keliais abiejų Vokiečių ordino šakų bandymais koordinuoti Lietuvos Didžiosios Kunigaikštystès puolimus. Butigeidžio (1285-1291 m.) ir Butvydo (1291-1295 m.) valdymo metais matome du tokius Ordino bandymus rengti puolimus kartu. Tai, žinoma, Vyteniui, pradejusiam valdyti 1295 m., nebuvo naujiena, nes jo valdymo metu Ordinas puldamas dar du kartus mégino derinti Livonijos ir Prūsijos veiksmus. Apskritai tokia Ordino taktika neturètų stebinti, nes nuo $1283 \mathrm{~m}$. Jotvos nukariavimo abi šio karinio Ordino šakas skyrè tik Žemaitija. Puikiai suvokta, kad stiprejja ir Lietuvos didžiųjų kunigaikščių pajègos, todèl situacija natūraliai vertẻ rengiant žygius prieš Lietuvą imtis bendresnès politikos. Nestebina ir Vytenio diplomatinès priemonès Livonijoje: didysis kunigaikštis neturejjo neišsemiamų išteklių, kad galètų ilgai kovoti su valstybę kone apsupusiu priešu. Glaudus bendradarbiavimas su Ryga vedè prie politikos, reikalaujančios ne tiek karinès jègos, kiek diplomatijos, kas iš tiesų ir buvo sẻkmingai igyvendinta.

41 Paszkiewicz H. Regesta Lithuaniae: ab originale usque ad Magni Ducatus cum Regno Poloniae Unionem. Tempora usque ad annum 1315 complectens. Varsoviae, 1930, t. 1, s. 90-177; Baranauskas T. Lietuvos valstybès ištakos. Vilnius, 2000, p. 177; Leonavičiūtè I. Kariauna Lietuvoje formuojantis valstybei // Magistro darbas, darbo vadovas E. Gudavičius, VU Istorijos fakulteto Senovès ir vidurinių amžių istorijos katedra. Vilnius, 1998, p. 65-72 (5 priedas). 
Grįžtant prie Ordino bandymų koordinuoti veiksmus, pradèti verta nuo Butigeidžio valdymo laikotarpio. Apie $1287 \mathrm{~m}$. lietuviai su žemaičiais išžygiavo ị Rygą, tačiau lygiai tuo pat metu, Haličo-Voluinès metraščio žiniomis, Torunès kryžiuočiai įsiveržè ị Žemaitiją ir, kaip skelbia šis metraštis, padėdami saviesiems, vokiečiams, paėmè belaisvių, o kitus žmones nužudè. Taip jie ramiai prisiplèšę grobio grịžo namo ${ }^{42}$. Šioje vietoje aiškiai pasakyta, kad, „padedami savo vokiečiams“, puolè Žemaitiją, bet ši ìvykị sunku suderinti su Petro Dusburgiečio kronikos duomenimis. Remiantis ukrainiečio Michailo Gruševskio datavimu, lietuvių ir žemaičių puolimas ịvyko 1287-1288 m. ${ }^{43}$ Deja, nèra jokių kitų kronikų duomenų apie tais metais vykusį Ordino puolimą ị Žemaitiją. Apie kitą abiejų Ordino šakų veiksmų derinimą sužinome iš $1290 \mathrm{~m}$. lapkričio mènesį rašyto Livonijos žemès magistro Halto laiško Prūsijos magistrui Meinhardui Kverfurtiečiui ${ }^{44}$. Laiške siūloma derinti veiksmus rengiantis bendram puolimui 1290 m. žiemą ${ }^{45}$.

42 Ипатьевская летопись. Полное собрание Русских летописей, 1962, т. 2, стб. 896897: „Ходиша Литва вса и Жемоть вса на Нъмцъ к Р1зи. И шнъм же въсть бы с и збъгошасА в городы шни же пришедъше к городоу не воспъвъ ничегоже и̃толь же идоша на Лотыголоу и доходивше города Мъдвъжьеи Головъ и не вспъвъше оу него ничто же и тако возвратишасА во свожси добывше мало полона се же оуслъшавше Тороуньсцьи Нъмцъ шже Жемоть всА пошла на Ригоу идоша на Жемоть помагаюче своимь Нъмцемь и поимаша ихъ бещисленое множьство а дроугиæ избиша и тако придоша во своæси со множествомъ полона.“

43 Грушевський М. Хронольогія подїй Галицько-волинської лїтописи // Записки Наукового товариства імені Шевченка, 1901, т. 41, с. 54. Zigmas Raulinaitis šią žinią datavo 1289 m., kai buvo statoma Ragainès pilis. Kaip priedanga buvo pasitelktas Torunès kryžiuočių būrys. Žr.: Raulinaitis Z. Lietuvos raiteliai. 5 knyga: Pakeliui ị galią, p. 109. Tokia galimybė yra, tačiau niekaip šaltinių nepatvirtinta. $1289 \mathrm{~m}$. įvyko daug ịvairių puolimų, tačiau aiškios nuorodos, kad susietumėme šiuos įvykius, neturime. Žinoma, negalime atmesti, kad Haličo-Voluinès metraščio žinutė yra apie 1288-1289 m. ịvykius, kai milžiniška, beveik 7000, žemaičių kariuomenè paremė žiemgalius. Šis ịvykis aprašomas Eiliuotojoje Livonijos kronikoje: Eiliuotoji Livonijos kronika // Mindaugo knyga. Istorijos šaltiniai apie lietuvių karalių (ats. sud. A. Dubonis). Vilnius, 2005, p. 353-356 (eil. 11089-11316).

44 Chartularium Lithuaniae..., p. 10-13.

45 Ten pat, p. 11: „Ir jeigu jums bei jūsų broliams pasirodys tinkama, jog galite ir norite dar šią žiemą išvesti kariuomenę prieš mūsų priešus lietuvius - būtent iš Žemaitijos - tuo pačiu metu su visomis savo pajègomis mes atskirai užgriūsime karaliaus Butigeido žemę, jeigu mums anksčiau kaip prieš tris savaites slaptu raštu nurodysite [tinkamą] dieną ir laiką." 
Magistras Haltas perspejja, jog jo suburta 1800 žmonių kariuomenė yra per silpna, kad galètų viena pulti, tad lauks ženklo; tačiau, jeigu jo nebus, Livonijos riteriai lauks žemaičių puolimo, ir tada jau žinia bus perduodama Prūsijai. Sprendžiant iš Hermano Vartbergiečio ir Petro Dusburgiečio informacijos, jokio bendro puolimo tą žiemą nebuvo ${ }^{46}$. Atsakymo reikètų ieškoti lyginant $1291 \mathrm{~m}$. Eiliuotosios Livonijos kronikos (toliau - ELK) informaciją su Petro Dusburgiečio žiniomis. ELK pateikiamos dvi žinios: pirmoji - apie magistro Halto žygị i Lietuvą, ko gero, 1291 m., antroji - apie lietuvių netikètą Kuršo puolimą, kurio metu žuvo žemaičių kunigaikščio Mažeikos (vok. Maseke) sūnus ${ }^{47}$. Petras Dusburgietis $1291 \mathrm{~m}$. priskiria kelis antpuolius - Kolainių sudeginimą, Junigedos valsčiaus apiplěšimą, Medrabos pilies sunaikinimą, Paštuvos ir Gaižuvos, Aukaimio valsčių nusiaubimus $^{48}$. Šių ỉvykių verpetuose $1291 \mathrm{~m}$. galejjo būti bent vienas bendras suderintas puolimas, tačiau nežinoma kuris.

Butvydas, tapęs didžiuoju kunigaikščiu apie $1291 \mathrm{~m}$., toliau organizavo žygius prieš Ordiną. Petras Dusburgietis jo valdymo laikotarpiu mini tik du žygius (1293 m. ir 1295 m.) prieš Ordino pilis. Savo ruožtu Prūsijos kryžiuočiai aktyviai puolè Kolainių pili, sunaikino Mederabės ir Kimelio pilis, plèše Aukaimio apylinkes. Ragainès komtūro Liudviko Libencelès iniciatyva buvo sudarytos paliaubos, jos truko apytikriai nuo 1294 iki $1300 \mathrm{~m}^{49}$. Šioje vietoje negarbingo karo politiką vykdè Lietuvos valdovas, nes po $1292 \mathrm{~m}$. Aukaimio apylinkių apiplěšimo kryžiuočiai Žemaitiją puolė tik 1300 m., o Vytenis 1299 m. užpuolè Notangą, 1300 m. - Varmės vyskupiją. Pažymėtina, kad pradiniame etape (1283-1307 m.) Ordino kariuomenè, vedama Karaliaučiaus komtūrų, nuolat rengé nedidelius žygius, tačiau jie nebuvo rezultatyvūs, kaip kad kovoje su prūsais, kuriuos išvargino

\footnotetext{
46 Eiliuotojoje Livonijos kronikoje yra Halto žygio, kurio metu jis puolè Lietuvą (matyt, Žemaitiją), aprašymas, tačiau nurodytas dalyvių skaičius nesutampa su $1290 \mathrm{~m}$. laiške pateiktais duomenimis, tuo labiau kad iš aprašymo akivaizdu, jog žygis vyko jau šiltuoju metų laiku, todèl, ko gero, tai buvo 1291 m. puolimas. Žr.: Eiliuotoji Livonijos kronika // Mindaugo knyga, p. 361-363 (eil. 11670-11793).

47 Eiliuotoji Livonijos kronika // Mindaugo knyga, p. 363-365 (eil. 11794-12017). Šis žygis datuojamas paskutiniojo XIII a. dešimtmečio pradžia - 1291 ar $1292 \mathrm{~m}$.

48 Petras Dusburgietis. Prūsijos žemès kronika, p. 224-227.

49 Ten pat, p. 233.
} 
nuolatiniais puolimais ${ }^{50}$. Žinoma, čia labai svarbi buvo didžiausia gamtinė kliūtis - Nemuno upè, kurią Ordino kariai turejjo kas kartą ịveikti. Sèkmé Butigeidžiui ir Butvydui nusišypsojo dèl tuo metu Ordiną sukrètusių nemalonumų. $1291 \mathrm{~m}$. krito jų ramstis Šventojoje žemejje - Akas, tad Ordinas turèjo ieškoti naujų namų. Be to, ši nesėkmẻ labai paveikẻ Ordino finansus ir - ne mažiau svarbu - prestižą. Tik XIV a. pr. pradejjo riteriai masiškai traukti ị Prūsiją, iš kur buvo organizuojami žygiai ị Lietuvos ir Žemaitijos žemes. Šiam procesui pasitarnavo $1308 \mathrm{~m}$. Vyslos kairiajame krante Rytu Pamario (Pomeranijos) ir Dancigo miesto užèmimas ${ }^{51} .1309$ m. šis karinis ordinas saugumo sumetimais perkèlè didžiojo magistro rezidenciją $\mathfrak{i}$ Prūsijos Marienburgą, kuris tapo jų sostine ${ }^{52}$ ir atsparos tašku rengiant puolamuosius žygius ị Lietuvos Didžiąą Kunigaikštystę ir Lenkiją.

Rygos miesto ir Ordino konflikto metu abi Ordino šakos bendradarbiavo dar labiau. 1296 m. žiemą (nežinoma, pradžioje ar pabaigoje) Vytenis ìsibrovė ị Livoniją, matyt, ketindamas paremti Rygą. Tuo metu Karaliaučiaus komtūras Bertoldas su didele kariuomene ketino pulti Vytenio žemes, tačiau kažkodèl nusprendè patraukti ị Gardino pilị̂. Iš šio veiksmo galime suprasti, kad Livonijos riteriai turèjo informuoti Prūsijos brolius. Panašus atvejis buvo nutikęs 1298 m. birželio mèn., kai atskubèjusios Prūsijos kryžiuočių pajègos, vadovaujamos Karaliaučiaus komtūro Bertoldo Briuhaveno, susijungè su Livonijos riteriais ir ties Nojermiulenu (Naujuoju Malūnu) sumuše lietuvių ir rygiečių kariuomenę ${ }^{54}$. Tuo metu didysis magistras pasiuntė Brandenburgo komtūrą Kūną su stipria kariuomene i Lietuvą, kad, J. Voigto žodžiais, Vytenis pasitrauktų ị savo žemę $e^{55}$.

Rokas Varakauskas teigia, kad prieš lietuvius 1298-1313 m. buvo ren-

50 Nikžentaitis A. Nuo Daumanto iki Gedimino: Ikikrikščioniškos Lietuvos visuomenès bruožai // Acta historica universitatis Klaipedensis. Vilnius, 1996, t. 5, p. 109.

51 Boochmann H. Vokiečių ordinas. XII jo istorijos skyrių. Vilnius, 2003, p. 114.

52 Ten pat, p. 122. Vokiečių ordinui buvo iškilęs rimtas pavojus, nes Klemensas V paskelbė miestui kryžiaus žygit, kai jis okupavo Ferarą. 1309 m. žymi naujo karo etapo - kryžiaus karo Žemaitijoje - pradžią. Žr.: Urban W. Kryžiaus karas Žemaitijoje, p. 36, 54.

53 Petras Dusburgietis. Prūsijos žemès kronika, p. 238.

54 Ten pat, p. 239

55 Ten pat, p. 240; Varakauskas R. Lietuvos valstybès pergalių prieš Livonijos ordiną XIII a. pab.-XIV a. pradžioje klausimu // Lietuvos TSR aukštųjų mokyklų mokslo darbai. Istorija, 1965, nr. 7, p. 138. 
giami atkaklūs žygiai, siekiant gelbèti Livonijoje esančius riterius ${ }^{56}$.

Iš turimų keturių (1287, 1290, 1296, 1298 m.) pavyzdžių matome, kad Ordinas bandè ieškoti būdų priešininkui, kuris spaudè iš abiejų pusių, ìveikti. Vis delto šie sunkiai apčiuopiami Ordino kariavimo ypatumai rodo, kad karo veiksmai galèjo būti koordinuojami, bet šaltiniuose tai neatsispindi. Ne visada tai Ordinui pavykdavo, tačiau konfliktas su Rygos miestu parodè, kad kryžiuočiai, rengdamiesi bendriems veiksmams, galejjo susivienyti, ko nepastebèta anksčiau, kol jų pajègos nebuvo priartèjusios prie Nemuno $1283 \mathrm{~m}$. Voplaukio mūšis veikiausiai rodo Vytenio sieki veikti vienodai aktyviai prieš abi Ordino šakas, suderinus veiksmus, kad nuolat nebūtų puldinejjama Lietuva, karinèmis ir diplomatinėmis priemonėmis palaikant jègų pusiausvyrą abiejuose frontuose ${ }^{57}$.

\section{PIRMASIS ŽYGIS İ PRŪSIJĄ}

Iš šaltinių sužinome, kad pirmą kartą Vytenis Prūsiją užpuole $1311 \mathrm{~m}$. per Užgavėnes (vasario $23 \mathrm{~d}$.) ${ }^{58}$. Jis su didele kariuomene nusiaubè Sembą ir Notangą ${ }^{59}$, paėmė beveik 500 belaisvių, dideli grobị, bet patyrè nuostolių, nes žuvo nemažai jo žmonių, kurie nutolo nuo pagrindinių pajègų ${ }^{60}$. Apie ši puolimą sužinome ir iš kitų šaltinių, kuriuose yra detalesnès informacijos. Vygandas Marburgietis Vytenio pajègas papildè rusais ${ }^{61}$. Jų da-

\footnotetext{
56 Ten pat.

57 Lenkų istoriko D. Prekopo nuomone, svarbiausios priežastys pulti Prūsiją buvo Vokiečių ordino konfliktas su Lenkija (prasidèjęs po 1308-1309 m. Gdansko Pamario šiaurès ir pietų dalies užkariavimo) ir pagalba Žemaitijai. Istorikas šių teiginių niekaip nepagrindžia, tačiau negalètume šių svarstymų atmesti kaip apskritai klaidingu ir nelogiškų, nes iš tiesų šie įvykiai buvo vienalaikiai. Žr.: Prekop D. Wojna zakonu krzyżackiego z Litwą w latach 1283-1325. Toruń, 2004, s. 117.
}

58 Petras Dusburgietis. Prūsijos žemès kronika, p. 256.

59 Sembos kanauninko ir Mikalojaus Jerošiniečio žinutès patvirtina puolimo kryptị: Canonici Sambiensis // SRP, 1861, Bd. 1, s. 282; Di Kronike von Pruzinlant des Nicolaus von Jeroschin // SRP, 1861, Bd. 1, s. 572 (eil. 23325).

60 Petras Dusburgietis. Prūsijos žemès kronika, p. 256.

61 Vygandas Marburgietis. Naujoji Prūsijos kronika, p. 64. 
lyvavimas tolesniame Vytenio žygyje patvirtinamas kronikininko Mikalojaus Jerošiniečio ${ }^{62}$. Atkreiptinas dèmesys ị žygio trukmę. Pasak šaltinio komentuotojų, Vygando Marburgiečio pateiktas netikslus skaičius - 80 dienų - atsirado neteisingai traktuojant Olyvos kronikos žinutę apie 18 dienų niokojimą ${ }^{63}$. Olyvos kronikoje sakoma, jog Vytenis 18 dienų siaubė Prūsijos žemes, tačiau nedetalizuojama ${ }^{64} .18$ dienų antpuolis - ittikinama veiksmų trukmè, nes ir kryžiuočiams, ir lietuviams paprastai reikèdavo bent savaitès kraštui užpulti ir nusiaubti ${ }^{65}$, o šiuo atveju buvo įsiveržta $\mathfrak{i}$ Prūsijos gilumą. Vygando Marburgiečio žinuteje teigiama, kad lietuvių pajègos priplèšto grobio neišlaikè, nes joms kelią pastojo Ordino suburtos „vèliavos“ (taktiniai koviniai vienetai). Pirmosios buvo ragainiečių, İsruties komtūro, vitingų, Šventojo Jurgio, Mergelès Marijos. Kartu šie Ordino kariai sumušè Vytenio pajègas. Iš kronikos aišku, jog tik Vytenis sugebejjo ištrūkti (pabėgo), o Ordinas triumfuodamas su grobiu (vedinas rusais, stabmeldžiais) grịžo namo ${ }^{66}$. Šioje vietoje matome šaltinių informacijos spragų, tad gali kilti abejonių dèl šio aprašymo tikrumo: kiti šaltiniai nepatvirtina, kad Vyteniui Prūsijoje buvo suduotas koks nors labai rimtas smūgis. Pasak Petro Dusburgiečio, Karaliaučiaus komtūras Fridrichas Vildenbergietis sekè lietuvius. Jie jau buvo išsiskirstę ir neapdairūs, todèl komtūras nusiaubè Pagraudès valsčių ${ }^{67}$. Vygandas Marburgietis ši incidentą paverčia dar neaiškesniu, nes tvirtina, jog Vytenis ateityje žygiuodamas bus užtikrintas dèl savo sẻkmès, tačiau prieš tai jo žinutèje teigiama, kad šis žygis ne visai pavyko. Viena vertus, galime numanyti, kad Vyteniui pats puolimas buvo sèkmingas, tačiau jo pabaigoje jis neteko

62 Di Kronike von Pruzinlant des Nicolaus von Jeroschin // SRP, 1861, Bd. 1, s. 577 (23698): „<...> rûsichen schutzin <...>“.

63 Vygandas Marburgietis. Naujoji Prūsijos kronika, p. 251 (2 komentaras).

64 Die altere chronik von Oliva // SRP, 1861, Bd. 1, s. 710.

65 Vytenis Almonaitis yra apskaičiavęs, jog XIV a. Vokiečių ordinui nužygiuoti ị Žemaitiją prireikdavo pustrečios savaitès, o siautimai vykdavo apie 10 dienų. Žr.: Almonaitis V. Kaltinėnų kraštas XIV a. antroje pusėje - XV a. pradžioje // Vakarų Lietuva XIII-XV a. Kaunas, 2013, p 41. Panašių apmąstymų yra pateikęs Z. Raulinaitis: Raulinaitis Z. Lietuvos raiteliai. 5 knyga: Karaliaus palikimas, p. 230.

66 Vygandas Marburgietis. Naujoji Prūsijos kronika, p. 64.

67 Petras Dusburgietis. Prūsijos žemès kronika, p. 257; Urban W. Kryžiaus karas Žemaitijoje, p. 78: „Jis pasiekè vieną didžiausių šio laikotarpio pergalių.“ 
kažkiek karių, tad didžiajam kunigaikščiui teko trauktis nestojant ị kovą. Jeigu Ordinas būtų dar Prūsijoje sudavęs stiprų smūgị Vyteniui, žygiuoti ì Pagraudę būtų nereikèję, todèl ši Vygando Marburgiečio epizodą galime traktuoti kaip neatitinkantị ìvykių logikos ${ }^{68}$. Ordinas dar spèjo (Vyteniui negrịžus atgal) surengti žygi i Gardiną, ten nukovẻ daug žmonių ir karių, grị̌zančių iš Prūsijos ${ }^{69}$. Tikètina, kad čia kalbama apie rusų šaulius, kurie keliavo ị Gardiną.

\section{ANTRASIS ŽYGIS İ PRŪSIJĄ}

Tolesni Vytenio veiksmai vyko jau daugiau nei po mènesio - $1311 \mathrm{~m}$. Verbų sekmadienio išvakarèse. Šio žygio priežastis, manytina, galejjo būti Vokiečių ordino magistro Zygfrido Foichtvangeno mirtis $1311 \mathrm{~m}$. kovo $5 \mathrm{~d}$. Trumpa suirutè Ordine iki naujojo magistro - Karolio Tryriečio išrinkimo buvo gera proga pulti Prūsiją antrą kartą ${ }^{70}$.

Balandžio $3 \mathrm{~d}$. Vytenis įsibrovẻ ì Prūsijos žemę su keturiais tūkstančiais rinktinių vyrų (lot. virorum preelectorum), nusiau-

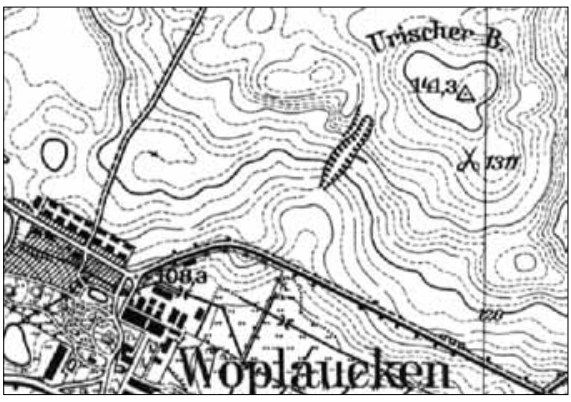

1938 m. vokiškame žemèlapyje (iškirptame fragmente) pažymèta Voplaukio mūšio vieta. Šaltinis: Rastenburg Jahr 1938 Digitalisat von MAPSTER Archivkarten von Polen und Mitteleuropa // http://wiki-de.genealogy.net/ Woplauken bė Varmès vyskupiją ${ }^{71}$, žemes

68 Vygando Marburgiečio kronikos komentuotojai yra pastebejję, kad kronikininkas dažnai nepaisè chronologijos.

69 Petras Dusburgietis. Prūsijos žemès kronika, p. 257.

70 Prekop D. Wojna zakonu krzyżackiego z Litwą w latach 1283-1325. Toruń, 2004, s. 119 (D. Prekopo manymu, priežastis galejo būti ir noras atsirevanšuoti už ne visai sẻkmingą ankstesnị žygi).

71 Ten pat, p. 258. 
iki Brunsbergo (dab. Braniewo) ${ }^{72}$. Toliau Petro Dusburgiečio ir Vygando Marburgiečio žinutès sutampa. Pirmasis teigia, kad „begédiškai išniekino bažnyčias, šventuosius rūbus bei taures, bažnyčios tarnus bei sakramentus", išsivarẻ daugiau kaip 1200 krikščionių belaisvių, nužygiavo į dykras Bartos žemèje, ị lauką, vadinamą Voplaukiu, ir ten ịsirengé stovyklą ${ }^{73}$ (1 priedas). Anot Petro Dusburgiečio, tame lauke jis tyčiojosi iš krikščionių sakydamas: „Kur jūsu dievas, kodèl jis jums nepadeda, kaip anksčiau mums padejo mūsu dievai dabar ir kitados?" ${ }^{\text {"77 }}$ Žinoma, krikščionys nieko negalëjo atsakyti. Vygandas Marburgietis pateikia dar išsamesnị aprašymą, kurio kilmė, pasak kronikos komentuotojų, galëjo būti ir sakytinè tradicija arba koks nors nežinomas mums šaltinis ${ }^{75}$. Kronikininkas pasakoja apie jau minètą tyčiojimąsi iš krikščionių ir Vytenio pasiūlymą dètis prie jo, nes jų - krikščionių - tikejjimas esąs tik apgavystė. Tai sakydamas, jis numetė ostiją ant žemès ir ją mindžiodamas kalbejo: „Ka gi jūs garbinate? Duona niekad nebus Dievu. Geriau žiūrèkite, koks aš galingas, ir atsiverskite ị stabmeldystę. “76

72 Di Kronike von Pruzinlant des Nicolaus von Jeroschin // SRP, 1861, Bd. 1, s. 575 (eil. 23509-23516). Martynas Murinijus mini Elsbergą, tačiau tai, ko gero, iškreiptas Brunsbergo pavadinimas, tačiau Murinijaus darbo komentuotojai ji sieja su pagal skambesi atitinkančiu Heilsbergu (dab. Lidzbark Warmiński), kuris yra arčiau Bartos žemès. Žr.: Marcin Murinius. Kronika Mistrzów Pruskich, s. 295 (381 nuoroda).

${ }^{73}$ Ten pat. Vietovès pavadinimo variacijų gali būti penkios, antai Sembos kanauninkas ir Trumpieji Prūsijos analai i̦vardija Lopelauken, Vygandas Marburgietis - Papilauken, Prūsų ekspedicijų analai - Weploc, Mikalojus Jerošinietis - Woplaukin, dabar - Wopławki. Ši vieta lokalizuojama ị šiaurès rytus nuo dabartinio Kentšyno (lenk. Kętrzyn; vok. Rastenburg; liet. Raistpilis).

${ }^{74}$ Petras Dusburgietis. Prūsijos žemės kronika, p. 258; Paaiškinimai, p. 423: „Šiuo epizodu Vytenis ragina lietuvius ir pavergtuosius prūsus laikytis senosios tèvų religijos ir kovoti prieš Ordino agresiją."

${ }^{75}$ Vygandas Marburgietis. Naujoji Prūsijos kronika, p. 251.

${ }^{76}$ İdomi D. Barono interpretacija šiuo klausimu: istorikas teigia, kad Vytenio veiksmai (krikščionybès niekinimas, prašymas prisidèti prie jo) buvo „savo galia pasitikinčio valdovo elgesys, kuriuo siekiama krikščionis belaisvius, paprastai sakant, padaryti savo valdiniais, kariais. <...> Todèl manome, kad ir Vytenis, niekindamas šventenybes, siekẻ krikščionių ištikimybę Dievui pakeisti ištikimybe sau, valdovui, kuris stengèsi tokiu būdu ịrodyti savo galios pranašumą “. Žr.: Baronas D. Trys Vilniaus kankiniai, p. 105-106. C. Rowello nuomone, šie Vytenio drąsiai ištarti žodžiai buvo tam tikra prasme pataikavimas pagoniškajai pusei, kad pagoniškasis pasaulis „nemanytų, jog didysis kunigaikštis išsižadèjo savo tèvų dievų". Taip buvo išlaikyta pusiausvyra tarp vietinès pagonybės ir merkantiliškos krikščionybės, ị kurią buvo sukama, ko gero, prekybos tikslais. Žr.: Rowell S. C. Iš viduramžių ùkų kylanti Lietuva, p. 62. 
Šie kunigaikščio žodžiai atrodo abejotini, nes, remiantis 1323 m. vasaros Gedimino laišku popiežiui Jonui XXII, tuo metu Vytenis jau state pranciškonams bažnyčią Naugarduke, kuri, manoma, $1314 \mathrm{~m}$. Ordino antpuolio metu buvo sunaikinta ${ }^{77}$. Tad Vytenio santykiai su krikščionimis tik gerejo. Juo labiau kad sutartis su Ryga (1298-1313 m.), nors ir apgaulinga, nes sudaryta siekiant išsaugoti prekybos kelius ị Rygą, garantavo kiek taikesni požiūrị i krikščionybę $e^{78}$. Be abejo, nereikètų pamiršti, kad kronikos autorius ruošia skaitytoją mūšio apibendrinimui, lyg norèdamas iš anksto parodyti tuščią pagonių puikybę $e^{79}$. Tokia ịkaitusi atmosfera (kaip ir popiežiaus legato Pranciškaus Molianiečio atvykimas ị Livoniją $)^{80}$ turẻjo lemti Lietuvai nenaudingus dezinformuojančius propagandinius šūkius.

Po kelių dienų - balandžio $7 \mathrm{~d} .^{81}$ - atžygiavo didysis komtūras Henrikas Plockietis su Karaliaučiaus pajėgomis ${ }^{82}: 150$ kryžiuočių su daugybe kitų karių $^{83}$.

77 Chartularium Lithuaniae..., p. 38-39: „Taip pat mūsų pirmtakas karalius Vytenis siuntè laišką ponui legatui Pranciškui ir ponui arkivyskupui Frydrichui, prašydamas, kad jam atsiųstų du brolius iš mažujų brolių ordino, skirdamas jiems vietą ir jau pastatytą bažnyčią. Tai žinodami, broliai iš Vokiečių namo [ordino] Prūsijoje pasiunte kariuomenę aplinkiniais keliais ir sudegino minètą bažnyčią <...>“; p. 326 (13 komentaras): „Gal čia kalbama apie 1314 m. užpuolimą, per kurị Ordino kariai sudegino visą Naugarduką?"; Petras Dusburgietis. Prūsijos žemės kronika, p. 265: „<...> užèmè Naugarduko miestą ir ji ligi pamatų sugriovè $<\ldots . .>$

78 Rowell S. C. Iš viduramžių ūkų kylanti Lietuva, p. 62-63.

79 Akivaizdu, kad visas Voplaukio mūšio aprašymas turèjo ideologini pagrindą, siekiant ịrodyti krikščionybès pranašumą ir pagonybès klaidingumą. Žr.: Prekop D. Wojna zakonu krzyżackiego z Litwą w latach 1283-1325. Toruń, 2004, s. 120 (20 komentaras).

${ }^{80}$ Liv-, Esth- und Curländisches Urkundenbuch nebst Regesten (1301-1367), hrsg. von F. G. Bunge, Reval [Tallinn], 1855, Bd. 2, s. 64-71 (nr. 638); Paszkiewicz H. Jagiellonowie a Moskwa: Litwa a Moskwa w XIII i XIV wieku. Warszawa, 1933, t. 1, s. 127 (1 nuoroda); Dubonis A. Traidenis: monarcho valdžios atkūrimas Lietuvoje (1268-1282). Vilnius, 2009, p. 108-109.

${ }^{81}$ Nustatyti tikslią Voplaukio mūšio datą nelengva. Petras Dusburgietis nurodo balandžio 8 d., Mikalojus Jerošinietis - balandžio 6 d. Sembos kanauninkas, Torunés analistas ir iš dalies Mikalojus Jerošinietis teigia, kad tai buvo Didžiosios savaitės trečiadienis, t. y. balandžio 7 d. Žr.: Vygandas Marburgietis. Naujoji Prūsijos kronika, p. 253 (3 komentaras).

82 Die Äeltere Hochmeisterchronik // SRP, 1866, Bd. 3, s. 586. „Des andern morgens Hinrich von Ploczk groszkumpthur na man sich dy bruder von Konigesberg, der wol LXXX was, dorczu manchen degin..."

${ }^{83}$ Petras Dusburgietis. Prūsijos žemès kronika, p. 258. 
Sembos kanauninkas pateikia kitus skaičius: didysis komtūras atsivedė 84 brolius ir $500 \mathrm{vyru}^{84}$. Mikalojus Jerošinietis ir juo sekę autoriai nurodo dar kitą $80^{85}$. Šioje vietoje labai neaiškūs šaltiniuose pateikiami duomenys (1 lentelè). Vygandas Marburgietis teigia, kad didysis komtūras atèjo su tomis pačiomis vèliavomis, kurios dalyvavo anksčiau atmušant Vytenio pajėgas, t. y. ragainiečių, Issruties, vitingų, Šventojo Jurgio, Holando ${ }^{86}$. Dabar jau mūšyje dalyvavo ir Kristburgo komtūras Giunteris Arnšteinietis, kuris atsivedè savo komtūrijos pajègas. Taigi iš viso prieš Vytenị stojo septynios kryžiuočių vẻliavos.

Vokiečių ordino karių skaičius Henriko Plockiečio vẻliavoje

\begin{tabular}{|l|l|}
\hline \multicolumn{1}{|c|}{ Šaltinis } & \multicolumn{1}{c|}{ Ivardytas kryžiuočiu skaičius } \\
\hline Sembos kanauninkas & 84 Ordino broliai su 500 vyrų \\
\hline Petras Dusburgietis & 150 Ordino brolių su daugybe žmonių \\
\hline Mikalojus Jerošinietis & Apie 80 vyrų \\
\hline Vyresnioji didžiujų magistrų kronika & 80 Ordino brolių \\
\hline
\end{tabular}

Kryžiuočių pajėgų kiekybinis modeliavimas neduoda ịtikinamų rezultatų. Kariuomenės dydžiui apskaičiuoti reikia kelių nekintančių rodiklių, t. y. bent vienos vẻliavos iečių skaičiaus ir XIV a. pr. Prūsijos demografinių duomenų, kurie leistų nustatyti galimas kiekvienos vietovės mobilizacines galimybes. Šiuo atveju žinomas tik netikslus didžiojo komtūro vèliavos karių skaičius: 150 - galimas didžiausias, 80 - mažiausias.

${ }^{84}$ Canonici Sambiensis // SRP, 1861, Bd. 1, s. 285: „<...> cum quingentis viris, quorum, fuerunt LXXXIIII fratres $<\ldots$. “.

85 Di Kronike von Pruzinlant des Nicolaus von Jeroschin // SRP, 1861, Bd. 1, s. 578 (eil. 23644); Die Äeltere Hochmeisterchronik // SRP, 1866, Bd. 3, s. 586.

86 Pirmojo Vytenio žygio ị Prūsiją metu viena iš vèliavų buvo įvardyta kaip „Mergelès Marijos“, antrajame žygyje minima, kad buvo ta pati vèliavų tvarka su „Holando [Švenčiausiosios] Mergelès paveikslu“. Vygando Marburgiečio kronikos komentuotojų teigimu, Mergelè Marija buvo pavaizduota Holando komtūrijos vèliavoje, todèl šiuo atveju manoma, kad kalbama apie tą pačią vėliavą. Žr.: Vygandas Marburgietis. Naujoji Prūsijos kronika, p. 252 (4, 6 komentarai). 
Remiantis Stefano Kuczyńskio tyrimu, ietị [taktinis vienetas - aut. past.] $1410 \mathrm{~m}$. sudarè 3 kariai (bet galejo sudaryti ir daugiau) ${ }^{87}$, todèl 150 riterių turèjo sudaryti 50 iečių, o 80 - apie 26 ietis. Atsižvelgiant ị tai, kad iš viso buvo 7 vẻliavos, idealiausiu atveju Ordino kariuomenę galèjo sudaryti 1050 kariu, o tai rodytų, jog Vytenio pajègos apytiksliai buvo keturis kartus gausesnès. Tačiau galima prielaida, remiantis Sembos kanauninko duomenimis, kad 1 vèliavą sudare 584 kariai, todèl 7 vẻliavas sudarytų 4088 kariai, be tarnų, esančių ietyje, kurie gerokai padidintų šị skaičių. Tačiau 4088 - kur kas realesnis skaičius, jis atitiktų šaltiniuose aprašomų Vytenio pajègų dydị. Problema ta, kad viduramžių Europoje buvo labai ịvairiai komplektuojamos kariuomenès. Skirtinguose mūšiuose dalyvaudavo skirtingas karių skaičius, tai priklausè nuo mobilizacinių galimybių, todèl nuolat svyravo ieties ir, suprantama, vèliavos karių skaičius ${ }^{88}$. Grị̌ztant prie Voplaukio karių skaičiaus problemos, reikètų atsižvelgti ị Sembos kanauninko duomenis, kurie rodo, kad vienam riteriui teko beveik 6 kariai. Istoriniai šaltiniai liudija, kad toks karių skaičius galimas ${ }^{89}$, tačiau net Žalgirio mūšyje, atsižvelgiant ị J. Dlugošo duomenis ir S. Kuczyńskio skaičiavimus, sunkiai tikètina, kad vèliavą būtų sudarę 500 karių $^{90}$. Todèl apie Voplaukio mūšyje dalyvavusių Ordino pajęgu dydị nieko tikslaus pasakyti negalime. Vokiečių ordinas turejo sutelkti pakankamas pajègas, kad galètų stoti i kovą su 4000 rinktinių karių. Reikia atsižvelgti ir $\mathfrak{i}$ Vytenio pajègų sudètį: iš tolesnès mūšio situacijos aišku, kad ne visi buvo raiti, o be visų atsivestų Lietuvos pajègų, dalyvavo ir rusų šauliai, todèl skaičius (4000) gali būti tik orientacinis. Jų, žinoma, galejo būti ir daugiau, tačiau nereikia atmesti versijos, kad šis skaičius yra gerokai padidintas, neturi realaus pagrindo.

Kodèl Vokiečių ordinas 4 dienas (balandžio 3-7 d.) delsè? Istoriografijoje tai aiškinama, pasak A. Nikžentaičio ir D. Barono, kokybiniu karybos pasikeitimu - atsirado kavalerija, taktinis Lietuvos kariuomenès vienetas, todèl rinktiniams raitininkams kryžiuočiai nedrịso stoti skersai kelio, kol

87 Kuczyński S. Wielka wojna z Zakonem Krzyżackim w latach 1409-1411. Warszawa, 1960 s. 221 (318 nuoroda).

88 Ten pat, s. 241, 220, 221 (318 nuoroda).

${ }^{89}$ Kuczyński S. Wielka wojna..., s. 221 (318 nuoroda).

90 Ten pat. Platesnis skaičiavimo pagal vèliavas problemos aptarimas: Ekdahl S. Jono Dlugošo „Prūsų vèliavos“ - Žalgirio mūšio šaltinis. Vilnius, 1992, p. 131-135. 
nesusirinko pagrindinès Ordino pajėgos ${ }^{91}$. Su šia nuomone neturètume visiškai sutikti, nes kavalerijos apraiškų buvo jau XIII a. pradžioje ${ }^{92}$. Vokiečių ordinui XIV a. pr. lietuvių karybos mokykla buvo puikiai pažistama, tad vargu ar koks nors antpuolis būtų galèjęs nustebinti patyrusius karius. Stoti ị mūši kryžiuočių kavaleristui prieš kitos pusès kavaleristą būtų dar naudingiau, nes iš šaltinių žinome, kad Ordino kariai vengẻ kautis pèsti, bet buvo igudę raiteliai ${ }^{93}$. Vis dèlto kyla klausimas, kodèl galutiniame susidūrime lietuviai nesikove raiti, nors iš šaltinių žinoma, jog po mūšio iš jų buvo paimta 2800 žirgų. Reikètų sutikti su D. Barono pastaba, kad lietuviai kartais ne tik patys apsitverdavo, bet ir savo žirgus aptverdavo užtvaromis, nes raiteliai iš esmès naudingesni per ataką puolant, o ne ginantis ${ }^{94}$. $\mathrm{Pa}-$ našu, jog Voplaukyje Vytenio kavaleristų pajėgos buvo per menkos, kad lygiaverčiai susikautų su raitais Vokiečių ordino kariais. Nors iš minètų 4000 karių dauguma buvo raiti (turejjo 2800 žirgų), bet jų, matyt, neužteko net rinktinei kavalerijai.

Keturias dienas Ordinas galëjo uždelsti ir dèl kitų priežasčių, apie kurias šaltiniai nekalba. Tikètina, kad tai iš dalies buvo padaryta dèl religinių paskatų - katalikai tuo metu minèjo Didžiąją savaitę (Vytenis, matyt, tuo taip pat galejo pasinaudoti organizuodamas puolimą), todèl nesitikejjo atakos. O gal dèl kitų veiksnių - atstumo, klimato sąlygų, kariuomenės susirinkimo laiko ${ }^{95}$. Nereikètu atmesti ir to, kad judresni raitininkai sunkiai pagaunami, todèl Ordino pajègoms dar reikẻjo rasti Prūsijoje greitai

91 Nikžentaitis A. XIII-XV a. lietuvių kariuomenės bruožai // Karo archyvas, t. 13, 1992, p. 21; Baronas D. Lietuvių karyba XIII a., p. 42.

92 Vitkūnas M. Kada lietuviai pradèjo kautis raiti? // Lituanistica, 2011, t. 57, nr. 1(83), p. 54-65; Vitkūnas M. Baltų karybos vèlyvajame geležies amžiuje (IX a.-XIII a. pr.) bruožai // Karo archyvas, t. 28, 2013, p. 37-38.

93 Saulès mūšio (1236 m. rugsèjo 22 d.) aprašyme teigiama, kad kryžiuočiai bijojo prarasti savo žirgus ir stoti ị kovą pėsti. Žr.: Eiliuotoji Livonijos kronika // Mindaugo knyga. Istorijos šaltiniai apie lietuvių karalių (ats. sud. A. Dubonis). Vilnius, 2005, p. 225 (eil. 1920-1925).

94 Baronas D. Lietuvių karyba XIII a. // Karo archyvas, 2000, t. 16, p. 15, 18.

95 W. Urbanas pateikia gana logišką versiją, kodèl būtent tuo metu buvo pulta: „Pražygiavęs atodrèkio metu per ežerų rajoną ir sugebėjęs išvengti susidūrimo su Vokiečių ordino ir Mazovijos kunigaikščių žvalgais, jis nušlavė Varmę iki pat jūros“ (Urban W. Kryžiaus karas Žemaitijoje, p. 79). Atodrèkis iš tiesų galejo sulaikyti pajègas, žygiuojančias ị kovos lauką. 
manevruojančias priešo pajègas.

Vytenio pajègos tuo metu jau buvo užėmusios gynybos (defenzyvinę) poziciją aukštumoje ${ }^{96}$. Nežinia tik, ar apsitverta medžių užtvaromis iš visų pusių buvo vos apsistojus Bartoje, ar jau sužinojus apie artẻjančius Ordino karius. I užtvaras atkreipia dėmesị Petras Dusburgietis, Mikalojus Jerošinietis ir Vygandas Marburgietis ${ }^{97}$. Tokia žiedinès gynybos taktika lietuvių karyboje buvo taikoma gana dažnai. Gynybos žiedo viduryje didžiojo kunigaikščio pajègos susiskirstė flangais. Iš šaltinių aišku, kad lietuvių ir rusų kariai sudarė skirtingus pulkus ir gynèsi skirtingais ginklais. Tolesnis mūšio aprašymas gana neaiškus, nes Vygandas Marburgietis teigia, kad gynybos žiedas buvo apsuptas, vadinasi, kryžiuočių pajègos išsiskaidè. Greičiausiai sunkioji kavalerija buvo sutelkta prie silpnesnių aptvaro dalių, o likusios pajègos apsupo žiedą.

Vokiečių ordino kariuomenè supo išsirikiavusi bent trimis pulkais. Pirmasis bandè smogti Henrikas Plockietis, tačiau jo smūgis buvo atremtas. Didysis komtūras prarado nuo 40 iki 60 vyrų $^{98}$. Mikalojus Jerošinietis teigia, jog iš už aptvaro Vytenio pajègos pašèlusiai gynèsi svaidydamos ietis

\footnotetext{
96 Augusto Kolbergo darbe $(1875$ m.) pateikta nuomonè dèl Voplaukio mūšio ne atvirame lauke, o miško proskynoje, nes Vytenio kariuomenè buvo gausi, o paimtų į nelaisvę daug ( 1200). Paimtieji ị nelaisvę turèjo būti saugomi miške prie Voplaukio lauko. Žr.: Prekop D. Wojna zakonu krzyżackiego z Litwą w latach 1283-1325. Toruń, 2004, s. 119, 120 (22 komentaras). Tokia įvykių eiga galima, nes tai paaiškintų, kodèl lietuviai nesikovė raiti, o taikèsi prie jiems patogesnių miško sąlygų, tačiau nè viename žinomame šaltinyje neužsimenama apie tokią ịvykių eigą, todèl šis argumentas abejotinas.

97 Petras Dusburgietis. Prūsijos žemès kronika, p. 258: „<...> užèjo karalių bei jo kariuomenę, iš visų pusių apsitvėrusią užtvaromis <...>“; Di Kronike von Pruzinlant des Nicolaus von Jeroschin // SRP, 1861, Bd. 1, s. 576 (eil. 23672-23678): „<...> von im und von sînen rotin / sô gezlîch was irbotin. / Und dô sî nâhin begundin, / di heidin sî dâ vundin / impor ûf einem berge / dî lenge und dî twerge / mit hegenen vorzingilt"; Vygandas Marburgietis. Naujoji Prūsijos kronika, p. 65: „<...> apsupo stabmeldžių kariuomenę, kurią užpuola iš visų pusių <... >“.

98 Petras Dusburgietis nurodo 40, Mikalojus Jerošinietis - 60. Di Kronike von Pruzinlant des Nicolaus von Jeroschin // SRP, 1861, Bd. 1, s. 576 (eil. 23683); Petras Dusburgietis. Prūsijos žemès kronika, p. 258.
} 
ir buožes (arba kuokas) ${ }^{99}$, kad atrodè lyg snigtų ${ }^{100}$, o rusų šauliai šaudè iš lankų. Antrasis puolimas įvyko Kristburgo komtūrui Giunteriui Arnšteiniečiui su vienu būriu užpuolus rusų šaulių saugomą aptvaro vietą. Po trumpo puolimo komtūro ataka nustelbẻ šaulius, kurie nebepajègė gintis ir praleido Ordino pulkus ${ }^{101}$. Užtvara buvo pralaužta ir pro ją pradejo plūsti kitos kryžiuočių pajègos ${ }^{102}$. Galų gale Kristburgo komtūras pasiekè apsitvèrusiųjų centrą. Lietuvių pajègų branduolyje kilo panika, matyt, tuo

99 Mikalojus Jerošinietis rašo „kuilen unde sper“, Vyresniojoje didžiųų magistrų kronikoje - „speren und kewlen“, Lukas Davidas ir Johanas Voigtas - „reulen“. Tiesiogine žodžio keule reikšmè - kuoka, tačiau tas pats žodis gali reikšti ir buožę. Pavyzdžiui, lotyniški šio žodžio atitikmenys - clava, fustis, femur - tinka ir kuokai, ir buožei įvardyti (Deutsches Wörterbuch von Jacob Grimm und Wilhelm Grimm. Leipzig: Hirzel, 1936, Bd. 11, Sp. 648.). Buožę sudaro medinis (arba metalinis) kotas su metaline nejudančia galva. Abejotume, ar kuoka buvo svaidyti pritaikytas ginklas, ir apskritai, ar ji buvo naudojama XIV a. karyboje, tačiau kyla problema dèl buožès, kuri iš esmès yra artimosios kovos ginklas. Svaidoma buožè iš tiesų gali padaryti daug žalos, tačiau istorijos šaltiniuose neužfiksuota, kad ji būtų buvusi naudojama kovoje per atstumą. Archeologas Manvydas Vitkūnas, aprašydamas ankstyvojo ir vėlyvojo geležies amžiaus karybą, yra pateikęs nuomonę, kad buožès galejo būti svaidomos (Vitkūnas M. Baltų karybos ankstyvajame geležies amžiuje (V-I a. pr. m. e.) bruožai // Karo archyvas. Vilnius, 2007, t. 22, p. 15; Vitkūnas M. Baltų karybos vèlyvajame geležies amžiuje (IX a.-XIII a. pr.) bruožai // Karo archyvas, 2013, t. 28, p. 22). Romas Batūra teigia, kad buožès buvo svaidomos ị riterius, tačiau jokių šio veiksmo pavyzdžių nepateikia (Batūra R. Karinė organizacija Lietuvoje XIII-XIV a. // Lietuvių karas su kryžiuočiais. Vilnius, 1964, p. 90). Buožès svaidymo pavyzdị randame Bajo tapiserijoje (ang. Bayeux Tapestry), vaizduojančioje $1066 \mathrm{~m}$. Hastingso mūši, todèl, mano manymu, Voplaukio mūšyje besiginantys lietuviai svaidè ne kuokas, o buožes. T. Hirscho teigimu, keulen (kaip ir šaltiniuose pasitaikantys kmitteln ir combucas) reiškia dviašmenị kovos kirvị (Jučas M. Žalgirio mūšis. Vilnius, 1999, p. 184), tačiau viduramžiams būdingas terminų nekonkretumas neleidžia konkrečiai pasakyti, koks ginklas buvo naudotas mūšyje.

100 Di Kronike von Pruzinlant des Nicolaus von Jeroschin // SRP, 1861, Bd. 1, s. 577 (eil. 23692-23694): „wurfin kuilen unde sper / kegn den cristen abe her / rechte als ob iz snîte“. Simonas Daukantas „Istorijoje žemaitiškoje“ šią vietą vertė ne „sniegas“, kaip kad nurodo Mikalojus Jerošinietis (snîte), o „kruša“: „, „..> berdami ir krūšą akmenų ir vylyčių ant vokyčių <...> “. Šis vertimas, nors ir netikslus, yra logiškas, nes mètomos ietys ir buožès (kuokos) turèjo atrodyti kaip kruša, o ne kaip sniegas (Daukantas S. Istorija žemaitiška. Vilnius, 1995, t. 1, p. 510).

${ }^{101}$ Di Kronike von Pruzinlant des Nicolaus von Jeroschin // SRP, 1861, Bd. 1, s. 577 (eil. 23695-23713).

${ }^{102}$ Voigt J. Geschichte Preussens. Königsberg, 1830, Bd. 4, s. 281. 
pasinaudojo Henriko Plockiečio kariai, taip pat įsiveržę ị lietuvių įtvirtinimą (2 priedas).

Kertinis šio epizodo momentas - Giunterio Arnšteiniečio Vytenio pajègų išskaidymas ${ }^{103}$, kas sukèlè destrukciją gynybinèje rikiuotèje. Petro Dusburgiečio teigimu, net į nelaisvę paimtos moterys „užmiršo savo lyties trapumą ir staiga užpuole lietuvius, kurie jas visai neseniai saugojo"104. Lietuviai ir rusai pasileido bègti, bet pavyti buvo žudomi ginklais ${ }^{105}$, galbūt kariami ${ }^{106}$ arba skandinami ${ }^{107}$. Petras Dusburgietis hiperbolizuodamas teigè, kad kariai patys iš sielvarto korèsi ${ }^{108}$. Užsimenama, kad išgyveno tik Vytenis ${ }^{109}$ su trimis savo kariais ${ }^{110}$. Ordinas paèmé 2800 žirgų ir nesuskaičiuojamą daugybę grobio. Belaisviai, be abejo, buvo išgelbèti ${ }^{111}$. Šios pergalès proga Torunejje buvo funduotas moterų vienuolynas ${ }^{112}$.

Tikslus Vytenio pajègų žuvusiųjų skaičius neaiškus (2 lentelè). Iš daugumos šaltinių žinoma, kad beveik visi Vytenio kariai buvo nukauti, todèl, jeigu imsime tikètiną pradinị skaičių, kurị nurodè Petras Dusburgietis (4000), galime modeliuoti bendrą šiek tiek daugiau negu 4000 karių skaičių. Atkreiptinas dèmesys ir ị Sembos kanauninko žinutę, kad žuvusiųjų buvo apie 3000. Vienaip ar kitaip, šis skaičius kardinaliai nesiskiria nuo

103 Ten pat, s. 282 (5 nuoroda).

${ }^{104}$ Petras Dusburgietis. Prūsijos žemès kronika, p. 258.

${ }^{105}$ Die Äeltere Hochmeisterchronik // SRP, 1866, Bd. 3, s. 586; Petras Dusburgietis. Prūsijos žemès kronika, p. 258

${ }^{106}$ Murzyński M. Kronika, abo Opisanie ziemie y Mistrzów Pruskich, s. 66; Jana Długosza kanonika krakowskiego..., s. 60.

${ }^{107}$ Jana Długosza kanonika krakowskiego..., s. 60; Stryjkovski M. Kronika polska, litewska, żmódzka i wszystkiéj Rusi, s. 351.

${ }^{108}$ Istoriko Dariaus Barono nuomone, panašūs Petro Dusburgiečio literatūriniai posakiai yra nuoroda i gėdą. Argumentuojama, kad barbarų visuomenės vyraujančios vertybès karinės, o atskaitos taškas - riba tarp garbès ir gèdos. Žr.: Baronas D. Lietuvių karybos bruožai XIII a. pradžioje // Lietuvos valstybė XII-XVIII a. Vilnius, p. 491.

${ }^{109}$ Petras Dusburgietis. Prūsijos žemès kronika, p. 258

${ }^{110}$ Di Kronike von Pruzinlant des Nicolaus von Jeroschin // SRP, 1861, Bd. 1, s. 578 (eil. 23796); Die Äeltere Hochmeisterchronik // SRP, 1866, Bd. 3, s. 587.

${ }^{111}$ Canonici Sambiensis // SRP, 1861, Bd. 1, s. 285: „<...> et redempti fuerunt Christiani circa mille et ducentos <...>“.

${ }^{112}$ Di Kronike von Pruzinlant des Nicolaus von Jeroschin // SRP, 1861, Bd. 1, s. 579 (eil. 23895); Die Äeltere Hochmeisterchronik // SRP, 1866, Bd. 3, s. 587. 
Petro Dusburgiečio duomenų. Šie skaičiai bent hipotetiškai atitiktų Vokiečiu ordino pajègų dydị.

\section{Žuvusiųjų skaičius skirtinguose šaltiniuose}

\begin{tabular}{|l|c|c|}
\hline \multicolumn{1}{|c|}{ Šaltinis } & Vytenio pajègos & Ordino kariai \\
\hline Prūsų ekspedicijų analai & Beveik 4000 & - \\
\hline Roneburgo analai & 23000 & - \\
\hline Sembos kanauninkas & Apie 3000 & - \\
\hline Petras Dusburgietis & Apie 4000 & 60 \\
\hline Mikalojus Jerošinietis & 4000 & 40 \\
\hline Vyresnioji didžiujų magistrų kronika & 4000 & 40 \\
\hline
\end{tabular}

Čia svarbu atkreipti dėmesị ị vieną Vygando Marburgiečio pasakojimo epizodą: kai Vytenis bėgo iš mūšio lauko, vienas karys vos neprakirto jam galvos. Kai netrukus buvo sudarytos paliaubos, Vytenis, naudodamasis proga, paklausė Ordino pareigūnų, kas buvo tas karys, kuris jị sužeidè. Magistras parodè ị kryžiuotị Duzemerị. Vytenis jam tarè: „Vos nenukirtai manęs savo aštriu kalaviju." O jis karaliui: - Taip būtu įvykę, jeigu būtumète manęs palaukęs. "113 Toks kunigaikščio elgesys XIV a. jau buvo retenybe $\dot{e}^{114}$.

Po šios, kartais vadinamos Pyro ${ }^{115}$, pergalès Ordinas èmè drąsiau veržtis į Žemaitiją ir Lietuvą. Vygandas Marburgietis po Voplaukio mūšio ịterpia žinutę apie anksčiau minètas trumpas paliaubas ${ }^{116}$, tačiau nežinoma, kiek jos truko ir ar apskritai nèra išgalvotos ${ }^{117}$. Jų tikètinas laikas - $1311 \mathrm{~m}$. liepos mėnuo (veiksmai Šalčininkuose), iki $1313 \mathrm{~m}$. vasaros (Bisenės puolimo). Gali būti, kad paliaubos buvo sudarytos dèl popiežiaus legato Pranciškaus Molianiečio atvykimo ị Livoniją ${ }^{18,}$ jis $1311-1312$ m. tyré Ordino

\footnotetext{
${ }^{113}$ Vygandas Marburgietis. Naujoji Prūsijos kronika, p. 65-66.

${ }^{114}$ Nikžentaitis A. Nuo Daumanto iki Gedimino, p. 45.

${ }^{115}$ Nikžentaitis A. XIII-XV a. lietuvių kariuomenès bruožai, p. 21.

${ }^{116}$ Vygandas Marburgietis. Naujoji Prūsijos kronika, p. 65: „Po trumpo tarpo sudaromos paliaubos $<\ldots$. "
}

${ }^{117}$ Nikžentaitis A. Nuo Daumanto iki Gedimino, p. 113.

${ }^{118}$ LUB, 1855, Bd. 2, s. 64-71 (nr. 638); Dubonis A. Traidenis, p. 108. 
skriaudas Rygos miestui ${ }^{119}$. Tokiu atveju paliaubos galejo ir neturèti nieko bendra su Voplaukio mūšiu.

Taigi, grižtant prie situacijos po Voplaukio, Brandenburgo komtūras Gebhardas Mansfeldietis $1311 \mathrm{~m}$. vasarą surengè niokojamąj žygi ̇ Pagraudès valsčių, ten viską sunaikino ir paemè grobio, bet pamatęs, kad prieš atejjūnus pasiruošę stoti vietiniai, nužudè visus paimtus ị nelaisvę žmones ${ }^{120}$. Vietiniai kilmingieji - Manstas, Masius, Sudargas ir kiti nestojo ị kovą, nes suvoké, kad kryžiuočiai bus surengęs pasalą. Vèliau jie pagrasino, kad Brandenburgo komtūras žus, jeigu dar taip rizikuos. Tuomet kažkoks lietuvis, Vytenio dvaro valdytojas - kamarininkas (lot. camerarius) ${ }^{121}$, laikomas Balgos pilyje, apgavo Ordiną: ji paleidę, kryžiuočiai surengė žygi ł ̣ardino pilị, tačiau šis lietuvis viską išdavė Vyteniui. Gardiną pulti ketino Voplaukyje pasižymėjęs maršalas Henrikas Plockietis su daugybe Ordino brolių ir 5000 karių, kurie, nežinodami apie išdavystę, žygiavo pilies link, tačiau, pagavę žvalgą, sužinojo apie lietuvių pasalą. Ordinas pasitraukè atgal, tačiau tai dar nebuvo pabaiga. Tas pats maršalas su stipria kariuomene - 150 Ordino riterių ir 2000 pèstininkų - pasuko i Šalčininkų valsčių (lot. territorium dictum Salsenickam) ${ }^{122}$, kur dar niekad nebuvo pasirodžiusi tokia didelè kryžiuočių kariuomenè. Šiame valsčiuje liepos 2 d. kryžiuočiai plèšikavo, žudè, sudegino tris pilis, o kitą dieną su 700 ị nelaisvę paimtų žmonių patraukè namo.

Tai buvo pirmas toks ịsiveržimas ị patị valstybès centrą. Sunku pasakyti, kas paskatino kryžiuočius atlikti tokị drąsų išpuolị. Istorikas Tomas Baranauskas mano, kad tai buvo „ị kampą užspeistų kryžiuočių, kuriems tuo metu grèsė popiežiaus pasmerkimas, desperatiškas puolimas, siekiant išplèsti savo valdžią ir galią" ${ }^{223}$. Tai būtų logiškas paaiškinimas, nes anksčiau

${ }^{119}$ K. Sideravičiaus nuomone, puolimų nerengta, matyt, dèl bado ir nederliaus, kuris tuo metu buvo Prūsijoje, Livonijoje ir Lietuvoje. Žr.: Sideravičius K. Lietuvos gynimasis nuo sustiprèjusios kryžiuočių agresijos 1295-1324 m. // Lietuvių karas su kryžiuočiais. Vilnius, 1964, p. 200.

${ }^{120}$ Petras Dusburgietis. Prūsijos žemès kronika, p. 259.

${ }^{121}$ Aukšto rango didžiojo kunigaikščio dvariškis, kuris buvo atsakingas už dvaro vidaus gyvenimą. Žr.: Petrauskas R. Ankstyvosios valstybinės struktūros Lietuvoje XIII amžiuje - XV amžiaus pradžioje // Lietuvos istorijos studijos, 2005, t. 16, p. 28.

122 Ten pat, p. 260.

${ }^{123}$ Baranauskas T. Šalčininkų istorijos pradžia - laisvès kovos. Interneto prieiga: 
minètos paliaubos (1311-1313 m.), atrodo, buvo sudarytos būtent po šių ivvkių, kad neišprovokuotų popiežiaus drastiškiems veiksmams.

Paradoksalu, kad kryžiuočiams, ịveikusiems Vytenio kariuomenę $1311 \mathrm{~m}$. Voplaukio mūšyje, siekiant padidinti savo ittaką ir galią, to teko griebtis, tačiau galų gale, kai sumažèjo popiežiaus nemalonės grèsmė, Vokiečių ordinas turèjo pristabdyti karinius veiksmus.

\section{KELIOS PASTABOS APIE ŠAULIUS XIII A. PABAIGOJE - XIV A. PRADŽIOJE}

Tuo metu ị Lietuvos karines pajègas neretai buvo įtraukiami ir rusai. Užkariautų žemių kariai turejjo dalyvauti bendroje politikoje. Archeologo Gintauto Rackevičiaus pastaba, kad nevertètų šaulių skirstyti pagal kilmę $e^{124}$, verta dèmesio, tačiau sunku suprasti, kodèl lietuviams taip dažnai talkino ne savi, o slaviškų žemių šauliai. Ankstyvesnèje istoriografijoje pažymèta, kad Vytenio valdymo pradžios šaltiniuose dažnai minimos ne tik „lietuvių pajègos“, o „lietuviai su rusais“125. Žinoma, buvo atvejų, kai minimi tik lietuviai šauliai ${ }^{126}$, tačiau didesnès karinès operacijos siejamos su rusais, ypač XIII a. antroje pusejje - XIV a. pradžioje, būtent tada, kai šaunamasis lankas lietuvių šaulių apskritai buvo mažai naudojamas ${ }^{127}$. Tai, kad padidejo rusų šaulių vaidmuo, ko gero, sietina su refleksinès (kompozicinès) konstrukcijos lankais, kurie buvo naudojami Rusioje jau XII a.

http://alkas.lt/2011/07/02/salcininku-istorijos-pradzia-\%E2\%80\%93-laisves-kovos/ [tikrinta 2012-03-01].

${ }^{124}$ Rackevičius G. Arbaletas ir lankas Lietuvoje XIII-XVI a. Vilnius, 2002, p. 41.

${ }^{125}$ Antanavičius V. Vytenis ir Gediminas 1293-1314 m. Vilnius, 1921, p. 8.

${ }^{126}$ Petras Dusburgietis. Prūsijos žemès kronika, p. 162: „Tuo metu stipri prūsų, sūduvių ir lietuvių kariuomenè ịsibrovė ị Sembos žemę<...> galop vieną dieną visi pakilo ị kovą, lankininkai [šaudè] strèles, apgulos mašinos [mètė] akmenis<...>“. G. Rackevičiaus nuomone, neabejotina, kad čia minimi lietuvių lankininkai. Žr.: Rackevičius G. Arbaletas ir lankas Lietuvoje XIII-XVI a. Vilnius, 2002, p. 41.

${ }^{127}$ Rackevičius G. Arbaletas ir lankas Lietuvoje XIII-XVI a. Vilnius, 2002, p. 42. 
Žinome, kad dar Traidenio valdymo laikais (1268-1282 m.) rusų šaulių pajėgos kariavo išvien su Lietuvos didžiuoju kunigaikščiu 1274 m. Daugpilio apguloje $\mathrm{e}^{128}$. Zigmas Raulinaitis iškèlè prielaidą, kad šie šauliai buvo iš geografiškai artimesnio Polocko ${ }^{129}$. Iš tiesų tai neprieštarautų susiklosčiusiai politinei situacijai.

1311 m. Vytenį lydėjo gausios šaulių pajègos. Dar 1311 m., Užgavėnių laikotarpiu, puolant Sembą ir Notangą remtasi rusų pajègomis. Petras Dusburgietis mini, kad po Vytenio atsitraukimo iš Prūsijos Vokiečių ordino brolis Otonas Bergietis su gausiomis pajègomis nužygiavo Gardino kryptimi, tačiau pasiklydo ir atsitiktinai pastebejo grị̌tančias Vytenio pajègas ${ }^{130}$. Kronikininkas kalba apie lietuvių karius ${ }^{131}$, tačiau Mikalojus Jerošinietis šiame epizode nemini ten buvus lietuvių ${ }^{132}$. Galime daryti prielaidą, kad šie besitraukiantys kariai buvo iš etniškai mišresnių Gardino apylinkių. Verta pridurti, kad Vygandas Marburgietis užsimena apie pirmojo žygio metu paimtus ị nelaisvę Vytenio rusus ${ }^{133}$. Manytina, jog šie besitraukiantys Gardino link kariai ir buvo rusų šauliai, kuriuos pavijo Ordino pajègos. Voplaukio mūšio ịkarštyje rusų šauliai ${ }^{134}$ lyg ir buvo paskirti ginti vienos užtvaros pusės, kurią atakavo Kristburgo komtūras. Pažymėtina, kad karinès pajègos nebuvo mišrios, greičiau - išskirtos.

\footnotetext{
${ }^{128}$ Eiliuotoji Livonijos kronika // Mindaugo knyga. Istorijos šaltiniai apie lietuvių karalių (ats. sud. A. Dubonis). Vilnius, 2005, p. 314 (eil. 8216-8219): „Rusų šauliai čionai atejo, / Prie Traidenio jie prisidejo: / Sužeidè iš lankų ne vieną, / Bet savo tikslo nepasiekè.“

${ }^{129}$ Raulinaitis Z. Lietuvos raiteliai. 5 knyga: Karaliaus palikimas. Kaunas, 1996, p. 187.

${ }^{130}$ Petri de Dusburg Chronicon terrae Prussiae // SRP, 1861, Bd. 1, s. 175-176.

131 Ten pat.

${ }^{132}$ Di Kronike von Pruzinlant des Nicolaus von Jeroschin // SRP, 1861, Bd. 1, s. 573-574 (eil. 23408-23449).

${ }^{133}$ Die Chronik Wingands von Marbug // SRP, 1863, Bd. 2, s. 454-455; Vygandas Marburgietis. Naujoji Prūsijos kronika, p. 64.

${ }^{134}$ Di Kronike von Pruzinlant des Nicolaus von Jeroschin // SRP, 1861, Bd. 1, s. 577 (23698): „<...> rûsichen schutzin <...>“.
} 


\section{VOPLAUKIO MŪŠIS: ISTORINĖ ATMINTIS}

Lietuviškoje istoriografijoje šiam mūšiui, kaip matome, daug dèmesio nebuvo skirta, todèl istorinèje atmintyje nèra susiformavusio jokio ryškesnio vaizdinio. Taip pat galima būtų kalbèti ir apie blankesnị didžiojo kunigaikščio Vytenio įvaizdị istorineje sąmonejje. Kita vertus - ir pagrịstai - nèra tradicijos minèti (ar paminèti) pralaimètų mūšių, kurie istorijos tèkmèje nebuvo labai reikšmingi. Tuo labiau kad daug kautynių ịvyko ne Lietuvos Didžiosios Kunigaikštystès teritorijoje. Šiandien Voplaukio mūšio laukas (kaip ir pietinè Prūsijos dalis) yra Lenkijos Respublikos teritorijoje, todèl dèl šių dviejų veiksnių - kad tai yra pralaimètas mūšis ir vyko kitos valstybès teritorijoje - nekyla jokių, Pierre’o Nora žodžiais tariant, kolektyvinès atminties vietos asociacijų. Voplaukio mūšio atminimą ịamžinti susirūpinta iš karto jam pasibaigus. Kaip rašo Petras Dusburgietis: „Šios šlovingos pergalès atminimui ir Jėzaus Kristaus garbei bei šlovei broliai įsteigè Torunès mieste moterų vienuolyną, kurị dosniai apdovanojo. "135 Vienuolynų fundacija, koplyčių ir bažnyčių statymas mūšių vietose buvo visai Europai būdinga tradicija. Puikus pavyzdys - Žalgirio pergalè, kuriai paminèti (tai buvo bažnytinès memoria kultūros dalis) Jogaila Liubline issteigè brigitiečių vienuolyną ${ }^{136}$. Torunès benediktinių vienuolynas, funduotas Vokiečių ordino didžiojo magistro Karolio Tryriečio, stovejo iki 1656 m., kol karo su Švedija metu buvo sugriautas.

1936 m. (625 metų sukakties proga) šalia Voplaukio lauko, ant vadinamojo Kruvinojo kalno, buvo pastatytas atminimo akmuo (žr. 3 priedą), ant kurio iškalti sukryžiuoti kalavijai ir mūšio data. Šis akmuo išliko iki šiol. Netoli akmens pastatyta ne itin išsami informacinẻ lentelè (žr. 4 priedą), kurioje pavaizduotas Vokiečių ordino riteris ir Lietuvos Didžiosios Kunigaikštystès karys.

\footnotetext{
${ }^{135}$ Petras Dusburgietis. Prūsijos žemès kronika, p. 259; Kurek J. Obserwancja zakonna toruńskich cysterek-benedyktynek w latach 1311-1632 // Sanctimoniales. Zakonny żeńskie w Polsce i Europie Środkowej (do przełomu XVIII i XIX wieku), BydgoszczToruń, 2010, s. 105-125.

${ }^{136}$ Mačiulis D., Petrauskas R., Staliūnas D. Kas laimèjo Žalgirio mūšįi? Istorijos paveldo dalybos Vidurio ir Rytų Europoje. Vilnius, 2012, p. 23.
} 
Šių dienų Lenkijoje (kaip ir Lietuvoje) istoriniai mūšiai tampa ịvairiausių rekonstruktorių klubų kasmete pramoga. Kautynių inscenizacijos, rengiamos profesionalių rekonstruktorių klubų, paprastai sulaukia daug visuomenès dèmesio. $2011 \mathrm{~m}$. Sofijos Licharevos Kenštyno krašto mègejų draugija ${ }^{137}$, minèdama $700 \mathrm{~m}$. Voplaukio mūšio jubiliejų, organizavo pirmąją šio mūšio inscenizaciją ${ }^{138}$. Šis įvykis paskatino nedideliame Voplaukio miestelyje, dabartinès Varmijos-Mozūrų vaivadijos Kenštyno valsčiuje, kasmet minèti šias kautynes. Jau ỉvyko tokie keturi istoriją ir archeologiją populiarinantys rekonstrukciniai renginiai, kuriuos padejo organizuoti kultūrą ir istoriją puoselëjančios organizacijos ir draugijos. Mūšio inscenizacijoje lenkų karo istorijos klubų nariai atlieka ir Vokiečiu ordino, ir Lietuvos Didžiosios Kunigaikštystès karių vaidmenis.

Susiklostė gana keista situacija, nes lietuviams aktualus mūšis apskritai Lietuvoje neprisimenamas, tačiau Lenkijoje, beveik neturinčioje jokio ryšio (išskyrus dabartinę teritoriją) su šiomis $1311 \mathrm{~m}$. kautynèmis, šis įvykis aktualizuojamas ir plačiai minimas, nors lietuvių pajègos ši susirèmimą su Vokiečių ordinu pralaimèjo. Pagrindinè Voplaukio mūšio inscenizacijos idejja - krikščionybès pergale prieš pagonybę, tačiau šių dienų Lenkijos istorijos entuziastai tokiu būdu stoja kryžiuočių (kaip krikščionybès nešèjų) pusèn. Istorijos paradoksas: 1308-1309 m. Vokiečių ordinas užkariavo Gdansko Pamario šiaurinę ir pietinę dalis, o $1309 \mathrm{~m}$. Vokiečiu ordino didžiojo magistro būstinè iš Venecijos buvo perkelta i Marienburgą. Pamario praradimas tų dienų Lenkijai buvo didžiulè netektis, ilgo konflikto, kurị laikinai išsprendè $1343 \mathrm{~m}$. Kališo taika, priežastis. Tačiau dar 1325 m. lenkai sudare sutartị su Lietuvos didžiuoju kunigaikščiu Gediminu, o $1326 \mathrm{~m}$. ịvyko pirmas bendras lietuvių ir lenkų žygis ị Brandenburgą. Šių istorinių ịvykių kontekste galima prisiminti, kad lietuvių situacija nebuvo geresnè, nes dar $1294 \mathrm{~m}$. Trojanovo mūšyje Vytenis sumušè Lenčicos kunigaikščio Kazimiero II kariuomenę. Taigi minint Voplaukio mūšio metines susiduriama su istorine dilema: XIV a. pr. nei Vokiečuu ordinas, nei lietuviai nebuvo lenkų sąjungininkai, atvirkščiai - nuožmūs priešai.

\footnotetext{
${ }^{137}$ Lenk. Towarzystwo Miłośników Ziemi Kętrzyńskiej im. Zofii Licharewej.

${ }^{138}$ Inscenizacja Bitwy pod Wopławkami. http://mragowo.muzeum.olsztyn.pl/inscenizacja-bitwy-pod-woplawkami,1090 [tikrinta 2014-11-12].
} 
Voplaukio mūšis nerado savo vietos lietuvių atmintyje, tačiau šiu dienų lenkų istorinè sąmonè sugebejjo beveik nieko bendro su savo istorija neturintị ịvykị dirbtinai su ja susieti per religiją ir mūšio vietą.

\section{BAIGIAMOSIOS IŠVADOS}

1. Voplaukio mūšio, ịvykusio $1311 \mathrm{~m}$. balandžio $7 \mathrm{~d}$., priežastimis tapo keli dalykai. Pirma, Lietuvos didžiojo kunigaikščio Vytenio siekis neleisti Vokiečių ordino šakoms - Prūsijai ir Livonijai - vykdyti koordinuotų karo veiksmų prieš Lietuvos Didžiąją Kunigaikštystę. Kaip tik dèl to Vytenis su abiem aktyviai kovojo tiek karinėmis, tiek diplomatinèmis priemonėmis. Antra, Vytenis pasinaudojo Vokiečių ordino magistro Zygfrido Foichtvangeno mirtimi ir trumpa suirute Ordino valstybeje, kas sudarè palankias sąlygas smogti kryžiuočiams. Tačiau neatmestina, kad palankios sąlygos susidarè Didžiąją savaitę (paskutinę savaitę prieš Velykas).

$2.1311 \mathrm{~m}$. ̣̇ Prūsiją buvo surengti du žygiai. Pirmasis puolimas vasario mèn. buvo nesèkmingas. Antrojo žygio metu ịvyko generalinis mūšis. Vytenio pajègos, sudarytos iš lietuvių raitelių, pėstininkų ir rusų šaulių, Bartos žemejje įsikūrẻ stovykloje, iš visų pusių aptvertoje užtvaromis (pasirengè žiedinei gynybai). Ordino pajègos, pasiekusios ịtvirtintą stovyklą, puolè dviem bangomis. Stovyklos gynejjai mètè ietis ir buožes, strèles (rusai). Antruoju puolimu pralaužus rusų šaulių saugomą užtvaro dalị, Lietuvos Didžiosios Kunigaikštystès pajėgos buvo išskaidytos. Jos pakriko, tad Vokiečių ordinas šventė pergalę.

3. Tikslus mūšyje kovojusių ir žuvusių karių skaičius neaiškus. Šaltiniuose pateikti itin abstraktūs skaičiai. Vytenis ị Prūsiją ịsiveržè su 4000 karių, beveik visi žuvo mūšyje. Išgyveno tik Vytenis su trimis kariais. Vokiečių ordino atvestų karių skaičius, šaltinių duomenimis, svyruoja nuo 80 iki 150 riterių, žuvusiųjų - nuo 40 iki 60. Tokie prieštaringi ir netikslūs duomenys neleidžia daryti konkretesnių išvadų.

4. Iš teksto analizès aišku, kad Voplaukio mūšis ir paskesni ịvykiai apipinti Vokiečių ordino propaganda. Kuriamas Vytenio, kaip krikščionybès 
priešo, ịvaizdis neatitinka jo realių santykių su krikščioniškuoju pasauliu: Vytenio bandymas pasikrikštyti ir Naugarduke pranciškonams statoma bažnyčia rodo ne itin radikaliai neigiamą požiūrị ị krikščionybę. Po mūšio kryžiuočiai pradejo aktyviau veržtis ị Lietuvos gilumą, tačiau, baimindamiesi popiežiaus sankcijų dẻl savo veiksmų, nutraukẻ puolimus ir su lietuviais sudarè trumpalaikes paliaubas (1311-1313 m.).

5. XIII a. II p. - XIV a. pr. Lietuvos valstybès karinèse operacijose neretai dalyvaudavo rusų pulkai. Dažniausiai šauliai, kurie, panašu, dèl igūdžių leisti strèles iš refleksinès konstrukcijos lankų buvo pranašesni už vietos šaulius, todèl greitai tapo sudedamąja Lietuvos Didžiosios Kunigaikštystès karinių pajègų dalimi, tačiau kartu buvo aiškiai išskiriama iš kitų karių grupių.

6. Voplaukio pergalę prieš lietuvius j̧amžinti Vokiečių ordinas ėmèsi iš karto po mūšio, Torunejje įsteigè moterų vienuolyną. Išskirtiniau įamžinti nemėginta iki pat XX a., todèl nesusiformavo ir jo minejimo istorinès tradicijos. Tik 1936 m. (625-ųjų metinių proga) šalia Voplaukio lauko, ant vadinamojo Kruvinojo kalno, buvo pastatytas atminimo akmuo. $1945 \mathrm{~m}$. Potsdamo konferencijos sprendimu pietinè Rytprūsių dalis atiteko Lenkijai, tad iš esmès teritorija ir joje kovoję priešininkai neturèjo istorinio ryšio su Lenkija. 2011 m., minint 700 metų mūšio jubiliejų, Sofijos Licharevos Kenštyno krašto mėgejų draugija surengė pirmąją Voplaukio mūšio inscenizaciją, tai paskatino šia proga kasmet organizuoti panašų renginị. Lietuvių istorinejje atmintyje Voplaukio mūšis nepaliko jokio vaizdinio. Tai iš dalies aiškinama tuo, kad mūšis buvo pralaimètas, o apie Lietuvos didịji kunigaikštị Vytenị (kaip ir jo epochą) apskritai mažiau žinoma. Voplaukis Lenkijos istorijoje rado savo vietą per religijos giją, demonstruojant krikščionybès pergalę prieš pagonybę.

Iteikta $2014 \mathrm{~m}$. balandžio $10 \mathrm{~d}$. 


\section{PRIEDAI}

\section{1 priedas}

Tikètinas Vytenio žygio maršrutas ir Voplaukio mūšio vieta

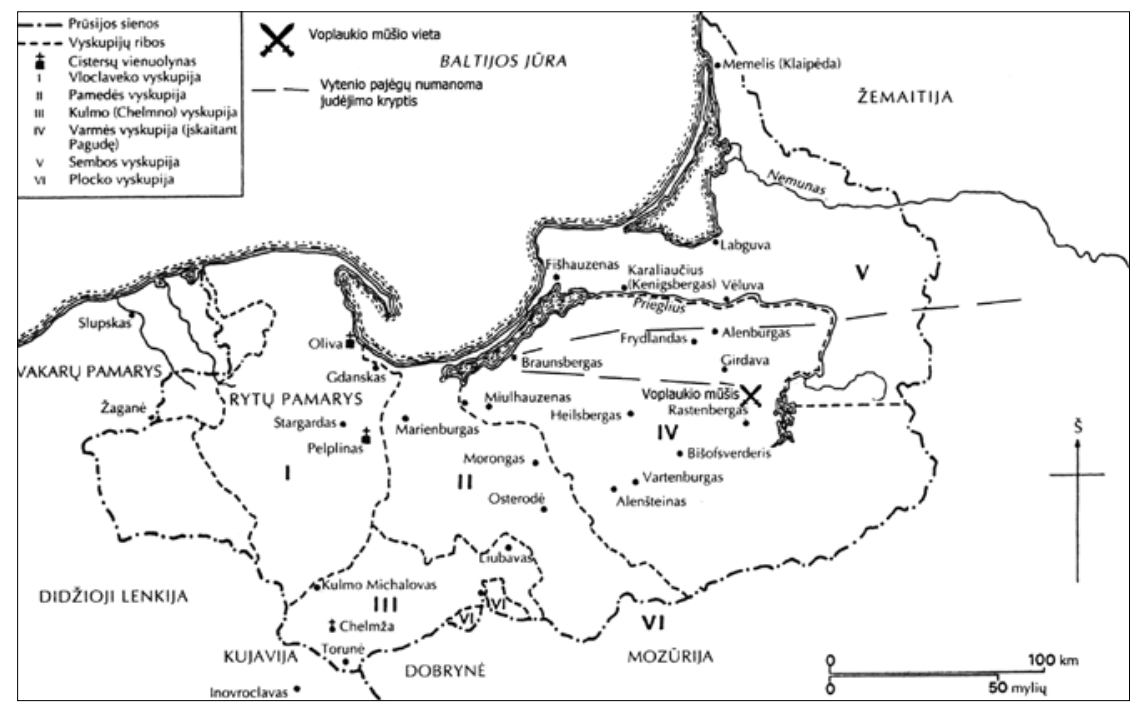

Žemélapis straipsnio autoriaus redaguotas. Šaltinis: Rowell S. C. Iš viduramžių ūkų kylanti Lietuva: pagonių imperija Rytų ir Vakarų Europoje, 1295-1345. Vilnius, 2001, p. XXII 


\section{2 priedas}

\section{$1311 \mathrm{~m}$. Voplaukio mūšio schema (autoriaus brèžinys)}

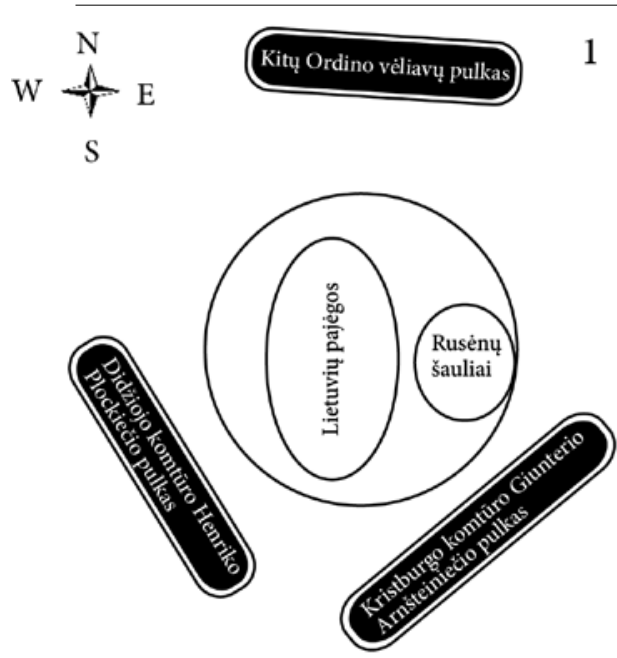

Vokiečių ordino pajègos atvyko ir apsupo Vytenio apsitverusius karius.

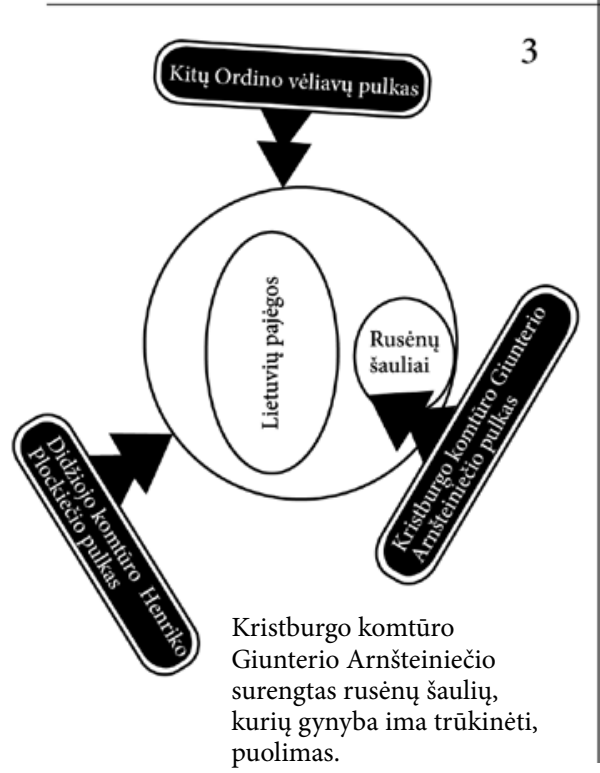

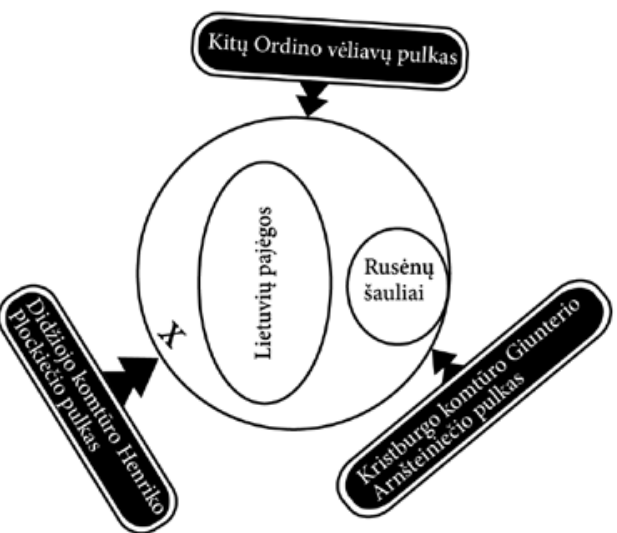

Pirmieji puola didžiojo komtūro Henriko Plockiečio kavaleristai, tačiau lietuviai atmuša ataką (x), jos metu kryžiuočiai prarado kelias dešimtis karių.

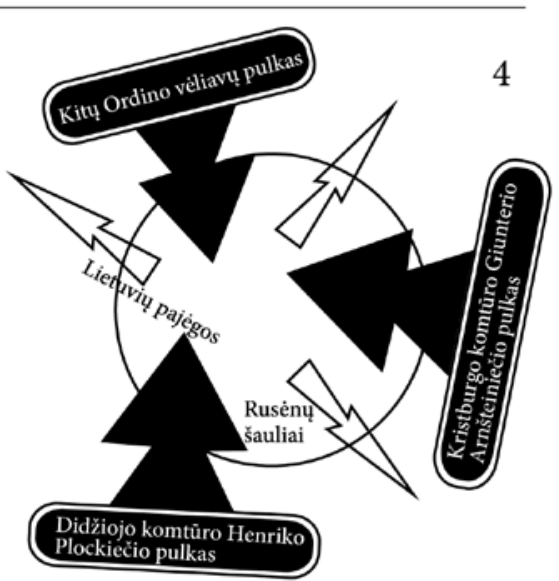

Giunteris Arnšteinietis prasiveržia pro rusėnų ginamas užtvaras ir sukelia chaosą Vytenio pajègų rikiuoteje. Tuo pasinaudoja Henrikas Plockietis. Jis prasiveržia prie lietuvių ir išblaško visas jų atvestas pajejgas. Vytenio kariai sprunka iš mūšio aptvarų ir mūšio lauko.

(c) Ričardas Dediala 


\section{3 priedas}

Voplaukio mūšiui skirtas atminimo akmuo, kuriame iškalta mūšio data

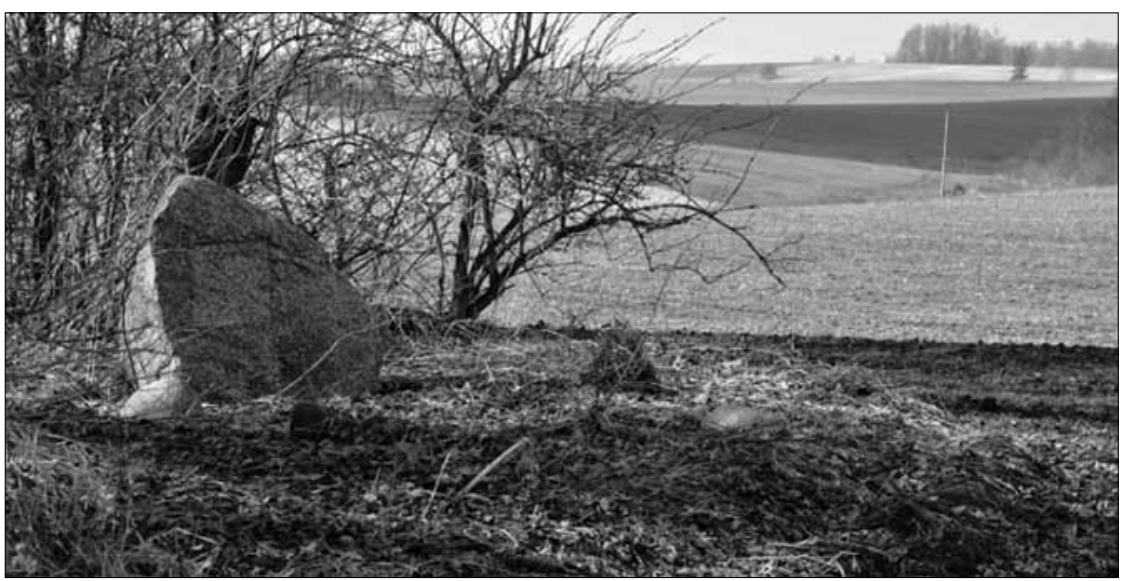

Nuotraukos šaltinis: http://www.miastoreszel.home.pl/iv-inscenizacja-bitwy-pod-wop-awkami---11-maja-2014r.-.html (Jolantos Grzyb nuotr.)

\section{4 priedas}

Informacinè lenta šalia Voplaukio mūšị žyminčio akmens

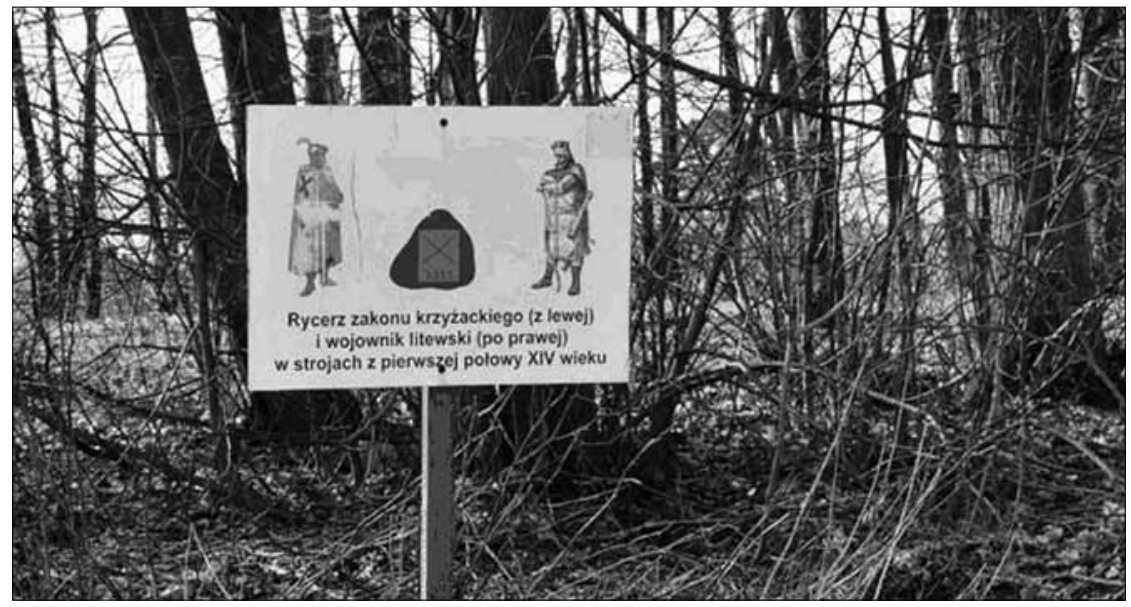

Nuotraukos šaltinis: http://www.reszel.pl/Spotkajmy_sie_maja_pod_Woplawkami,28,1983. html (Jolantos Grzyb nuotr.) 


\title{
LA BATAILLE DE WOPLAWKI EN 1311: CAUSES, DEROULEMENT, ASPECTS MILITAIRES, MEMOIRE HISTORIQUE
}

\author{
Ričardas DEDIALA \\ Université de Vilnius
}

Pendant le règne du Grand-Duc Vytenis (1295-1315), une guerre intensive contre l'Ordre Teutonique a eu lieu. Parmi les nombreux affrontements survenus à petite échelle, l'un d'entre eux a été l'une des plus grandes batailles du 14ème siècle et, de surcroît, infructueuse pour les forces armées de Vytenis; Mais elle a été extrêmement instructive d'un point de vue historique. La bataille de Wopławki s'est déroulée le 7 avril 1311. Deux raisons en sont la cause et marquent une période défavorable à l'Ordre Teutonique. En 1311, deux expéditions ont été lancées sur la Prusse. La première offensive de février a été un échec. La vraie bataille s'est produite lors de la deuxième attaque. Les forces de Vytenis, composées de la cavalerie lithuanienne, de l'infanterie et de tireurs russes, ont établi un camp clôturé de tous côtés par des palissades (appelées anneaux de défense) sur les terres des Bartiens. Une fois qu'elles ont atteint le camp retranché, les forces de l'Ordre ont attaqué en deux vagues successives. Les défenseurs du camp leur ont jeté des lances et des gourdins tandis que les tireurs russes ont usé de leurs arcs et de leurs flèches. À partir de la deuxième moitié du 13ème siècle, les régiments de tireurs russes faisaient entièrement partie de l'armée du Grand-Duché de Lithuanie, même s'ils étaient néanmoins tenus à lécart en tant que régiment de tireurs. Les forces du Grand-Duché de Lithuanie ont été divisées au cours de la deuxième attaque, après qu'une partie de l'anneau de défense protégé par les tireurs russes ait été percée. Ils se sont alors dispersé et l'Ordre Teutonique a célébré sa victoire. Le nombre exact de combattants et de guerriers morts au cours de la bataille est incertain. Les chiffres donnés dans les sources sont particulièrement abstraits, empêchant de s'en faire une image précise. En se basant sur l'analyse du texte, il est clair que la bataille de Wopławki et les événements 
postérieurs qui en ont découlé étaient une propagande de l'Ordre Teutonique. Ils ont fait de Vytenis un ennemi du christianisme, une image qui nétait pas conforme à la réalité et aux relations qu'entretenait le Duc avec le monde chrétien. Immédiatement après la bataille et afin de commémorer à jamais la victoire de l'Ordre Teutonique sur les Lithuaniens, ils ont établi à Torun un couvent pour femmes. Jusqu'au 20ème siècle, les tentatives pour commémorer cette bataille ont échoué et ce jusqu'en 1936 (à l'occasion du 625ème anniversaire), lorsqu'une pierre commémorative a été construite près du champ de Wopławki, sur la colline dite Sanglante. En 1945, au cours de la conférence de Potsdam, il a été décidé de remettre la partie sud de la Prusse orientale à la Pologne et, par conséquent, un territoire sur lequel se sont battus des ennemis sans aucun lien historique avec la Pologne. En 2011, pour commémorer le 700ème anniversaire de cette bataille, la société de Sofija Lichareva pour les amateurs de la ville de Kętrzyn ont organisé la première reconstitution historique de la bataille de Wopławki, incitant ainsi à réorganiser le même événement chaque année. La bataille de Wopławki n'a pas laissé une telle impression dans la mémoire historique lituanienne. Ceci est en partie expliqué par le fait qu'ils ont perdu la bataille et que généralement peu de choses sont connues au sujet de Vytenis, le Grand-Duc de Lithuanie (et de son époque). Wopławki a trouvé sa place dans l'histoire polonaise au travers de la religion comme la victoire du christianisme contre le paganisme. 


\title{
THE BATTLE OF VOPLAUKIS (1311): REASONS, COURSE, MILITARY ASPECTS AND HISTORICAL MEMORY
}

\author{
Ričardas DEDIALA \\ Vilnius University
}

During the reign of Grand Duke Vytenis (1295-1315), an intense war with the Teutonic Order took place. Among the many small-scale clashes, one of the biggest battles of the fourteenth century, which was unsuccessful for the Vytenis forces, however, very informative in terms of military history should be mentioned, namely, the battle of Voplaukis, which took place on 7 April 1311. There were two reasons for the battle, and they were driven to the time unfavourable to the Teutonic Order. In 1311, there were two marches to Prussia. The first attack in February was unsuccessful. The general battle took place during the second march. Vytenis forces consisting of Lithuanian cavalry and infantry, and Russian shooters settled in a camp in the Barthen land fenced on all sides (the so-called ring-defence). Horde forces reached the entrenched camp and attacked it in two waves. The camp's defenders threw spears, butts, and Russian shooters shot arrows from bows. From the second half of the thirteenth century, Russian shooter regiments were an integral part of the army of the Grand Duchy of Lithuania, but most often they were separated into a shooter regiment. When some part of the fence guarded by Russian shooters was broken during the second attack, the forces of the Grand Duchy of Lithuania were divided. They scattered and the Teutonic Order celebrated victory. The exact number of soldiers who fought and died in the battle is not known. Very abstract figures provided in the sources do not display a precise picture of the battle. It is clear from the analysis of the text that the battle of Voplaukis and subsequent events were interwoven with Teutonic Order propaganda. The image of Vytenis created as the enemy of Christianity did not disclose the real relations of the Duke with the Christian world. The Teutonic Order began to commemorate the victory of Voplaukis against the Lithuanians immediately after the battle, and established a 
nunnery in Torun.

Until the twentieth century, there were no attempts to commemorate the battle, but in 1936 (on the occasion of the 625th anniversary), near Voplaukis field, on the so-called Bloody Hill, a memorial stone was erected. In 1945, by the decision of the Potsdam Conference, the southern part of East Prussia went to Poland, so basically the territory and the opponents who were fighting there had no historical link with Poland. In 2011, to commemorate the 700-year anniversary of the battle, Sofia Lichareva Ketrzyn Land Amateur Society held the first dramatisation of the battle of Voplaukis, and this led to the tradition of organising a similar event each year. The battle of Voplaukis has left no image in the historical memory of Lithuanians. This is partly explained by the fact that the battle was lost, and, in general, little is known about Vytenis, the Grand Duke of Lithuania (and his era). Voplaukis in Polish history has found its place in respect of religion, demonstrating the triumph of Christianity over paganism. 